FILIP WRÓBLEWSKI

Uniwersytet Jagielloński

\title{
Brud i odraza, czyli jak się zostaje etnografem Część 1. Brud Innego
}

(...) zachowania i wyrażenia skupione wokót panicznego strachu przed "stanami, w których rozpuszczają się granice ciata". Brud, szlam, bagno, śluz, breja na określenie politycznie „innego" (...).

Klaus Theweleit (2009: 117)

Tiniejszy tekst ma naświetlić znaczenie higieny i zmysłowo doświadcza-
nego brudu w trakcie prowadzenia etnograficznych badań terenowych dla wyodrębniania i kształtowania podmiotowości antropologów. Radzenie sobie z nieczystościami, ryzykiem skalania, wstrętem i odrazą, dojmującymi zmysłowo i cieleśnie niedogodnościami, choć ujmowane anegdotycznie $\mathrm{w}$ relacjach $\mathrm{z}$ pracy badawczej, wydaje się stanowić jeden z ważniejszych faktorów wpływających na przebieg socjalizacji profesjonalnej $\mathrm{w}$ ramach praktyki antropologicznej. $\mathrm{W}$ analizie wskazanego zagadnienia zostaną wykorzystane teorie i koncepcje wypracowane w ramach poststrukturalizmu. Posłużą one do interpretacji materiału empirycznego zaczerpniętego ze źródeł archiwalnych oraz zapisów rozmów prowadzonych z polskimi etnologami ${ }^{1}$.

1 Publikacja stanowi rezultat projektów badawczych: „Etnografia jako doświadczenie osobiste. Generacyjne uwarunkowania przemian metodologii i praktyk badawczych", finansowanego przez Narodowe Centrum Nauki (2011-2013, grant nr 2011/01/N/HS3/03273), "Wyznaczniki dyskursu scjentystycznego w etnologii na przykładzie materiałów Polskiego Atlasu Etnograficznego" (2012-2013), "Znaczenie Międzyuczelnianych Obozów Etnograficznych dla rozwoju metodologii badań etnograficznych" (2013-2014), „Maria Znamierowska-Prüfferowa wobec dyskusji o programie nauczania etnografii” (2014-2015) oraz „Świadkowie 
W artykule poruszone zostały zagadnienia ogólne, wiążące się przede wszystkim z takimi konceptualizacjami Innego w dyskursie antropologicznym, które wykorzystują kategorie brudu i nieczystości. Towarzyszy im skrótowa rekapitulacja teorii antropologicznych skupiających refleksje nad ciałem i zmysłami. W odniesieniu do niej zostały również wskazane czynniki kontekstualizujące formowanie się dyskursu antropologicznego, które na przestrzeni XIX i XX wieku odegrały znaczącą rolę w kształtowaniu reżimu higienicznego właściwego społeczeństwom zachodnim.

Planowany kolejny artykuł, stanowiący kontynuację niniejszych rozważań, obejmować będzie trzy zagadnienia. Techniki siebie i formy (samo)dyscypliny praktykowane przez etnografów w trakcie prowadzenia badań terenowych, a także znaczenie brudu $\mathrm{w}$ procesie wyodrębniania i formowania podmiotu etnograficznego. $\mathrm{W}$ odniesieniu do nich będzie następnie przeprowadzona wiwisekcja dystynkcji odpowiadającej tej formacji zawodowej, wraz ze wskazaniem i analizą jej elementów konstytutywnych.

\section{Antropologia i zmysły}

Wydaje się, że o etnograficznych badaniach terenowych powiedziano już niemal wszystko. Wszak jedną z istotniejszych linii - postmodernistyczną z ducha - krytyki antropologii jako dyscypliny, a zarazem sposobu budowania wiedzy, było podważenie mitu przeźroczystości badacza. Problem jego wpływu na tworzenie reprezentacji życia przedstawicieli innych kultur, ale też bezpośrednio związane $\mathrm{z}$ nim powikłania etyczne i epistemologiczne $\mathrm{w}$ zdobywaniu informacji, ujawniły się z całą mocą w chwili publikacji A Diary in the Strict Sense of the Term w 1967 roku (Malinowski 1967). Publikacja intymnych zapisków Bronisława Malinowskiego wywołała szok i niedowierzanie, z czego wynikła żywiołowa debata (por. Firth 1989; Kubica 2008: 26-35); w rezultacie doprowadziło to do podważenia jednego z mitów założycielskich dyscypliny. Kryzys (w) antropologii zbiegł się z rewolucją obyczajową, która ogarnęła i następnie odmieniła przede wszystkim kapitalistyczne społeczeństwa zachodnie; kryzys ten stopniowo narastał, by osiągnąć apogeum w latach 80. XX wieku (por. Silverman 2007: 343-361), czemu najpełniejszy wyraz dał osławiony już tom Writing Culture pod redakcją George'a Marcusa i Jamesa Clifforda (1986).

Przemiany zachodzące wówczas na łonie antropologii w zasadniczej mierze tyczyły się form reprezentacji i krytyki dyskursu etnograficznego. Nie był to jednak jedyny, wyłączny czy choćby dominujący kierunek zmian. Równie ważna okazała się rewizja tematyki podejmowanej przez poszczególnych badaczy i jej

historii. Biografie naukowe polskich etnografów i etnologów starszego pokolenia" (2015-2016) finansowanych przez Wydział Historyczny Uniwersytetu Jagiellońskiego. Za pomoc okazaną w trakcie przygotowywania tekstu dziękuję Tarzycjuszowi Bulińskiemu, Magdalenie Dolińskiej, Elżbiecie Duszeńko-Król, Arturowi Sekundzie, Annie Sulich-Lidze, Janowi Tomaszewskiemu oraz Michałowi Żerkowskiemu. Kamilowi Pietrowiakowi dziękuję za zaufanie, wyrozumiałość i cierpliwość. 
znaczne poszerzenie (Ruby 1982; Turner, Bruner 2011; Jackson 1987), jak również poddanie refleksji i zachwianie jednoznacznością samej praktyki terenowej. Choć Writing Culture dzięki wprawnej i skutecznej promocji autorów zaangażowanych $\mathrm{w}$ to przedsięwzięcie uchodzić może za manifest posmodernizmu (Lubaś 2014; Majbroda 2014), nie jest to jedyny probierz trendów panujących $\mathrm{w}$ antropologii ostatnich trzech dekad XX wieku. Warto zatem zwrócić uwagę na szereg innych procesów prowadzących do rozszczelnienia i przeorientowania paradygmatów obowiązujących wówczas w antropologii światowej. Znamienne, że okres dojrzałego poststrukturalizmu przyniósł naukom społecznym zainteresowanie ciałem i tym, co związane ze zmysłami. Obie orientacje badawcze, choć zbieżne i wzajem przenikające się, w literaturze fachowej sytuują się w dwóch osobnych nurtach zorientowanych na embodiment bądź senses, czemu przyświecają różne założenia i odmienne rozłożenie akcentów (Csordas 1993; Turner 2000; Goody 2002; Pink 2009, 2010a, 2010b; Howes 2010a, 2010b; Majbroda 2013). Warto przy tym zaznaczyć, że owa tematyka była wprawdzie podejmowana wcześniej przez antropologów, czego przykładem są prace Les techniques du corps Marcela Maussa (2001: 389-413) z 1935 roku, Balinese Character Gregory'ego Batesona i Margaret Mead (1942) czy Purity and Danger Mary Douglas (2007) z 1966 roku, jednak nie stanowiła ona zasadniczego przedmiotu zainteresowania szerszego grona przedstawicieli dyscypliny. $Z$ czasem sytuacja ta miała ulec zmianie.

Tak oto poszukiwanie nowego języka w obrębie dyskursu antropologicznego oraz mniej akademickich perspektyw badawczych postępowało - jak się wydaje równolegle do rozwoju etnonauki (antropologii kognitywnej), stanowiąc reakcję na postulaty scjentystycznego purytanizmu. Badacze na nowo zaczęli zwracać uwagę na relacje między wiedzą, myśleniem a ciałem (Jackson 1983a, 1983b; Scheper-Hughes, Lock 1987). Jednym z pierwszych kroków, obok wspomnianej pracy Douglas, prowadzących ku nowej tematyce badawczej była zorganizowana w 1975 roku przez Association of Social Anthropologists of the Commonwealth konferencja poświęcona antropologii ciała. Jej wymiernym rezultatem stała się publikacja The Anthropology of the Body (Blacking 1977). Jednak większe znaczenie dla ugruntowywania pozycji opisywanej tu perspektywy miały indywidualne propozycje formułowane kolejno przez Michaela Taussiga (1986) Shamanism, Colonialism, and the Wild Man, Paula Stollera (1989) The Taste of Ethnographic Things i Thomasa Csordasa (1990) Embodiment as a Paradigm for Anthropology. Przy czym ujęcia Stollera i Csordasa należy uważać nie tylko za klasyczne, ale i za fundamentalne dla wytyczenia podstaw dalszych dyskusji o zmysłach i wiedzy ucieleśnionej. Przypieczętowaniem takiego stanu rzeczy były następnie przypadające na początek lat 90. XX wieku publikacje tomów zbiorowych The Varieties of Sensory Experience pod redakcją Davida Howesa (1991) oraz Embodiment and Experience przygotowanego przez Thomasa Csordasa (1994). Po skutecznym usankcjonowaniu w obrębie dyskursu antropologicznego nurt ten przyniósł wkrótce wiele rozwinięć i autorskich propozycji (Classen 1993; Taussig 1993; Classen, Howes, Synnott 1994; Stoller 1995; Csordas 2002; Howes 2005), doczekał się również 
literatury krytycznej, a koleje opisywanych tu zmian zostały dobrze opisane (Classen 1997; Howes 2003: 29-58).

Przypadające na lata 80. minionego stulecia wzmożona krytyka społeczna, rewizja roli i funkcji antropologii czy wreszcie przenicowanie etnografii ujmowanej zarazem jako swoisty gatunek i prowadząca do niego praktyka pisarska (Geertz 2000; Sanjek 1990) przyczyniły się do przedefiniowania polityki prowadzenia badań terenowych. Oto badacz jako fizyczna osoba a zarazem figura autorytetu (Clifford 2000) stracił na przezroczystości (Stocking 1983; Tokarska-Bakir 1995). Widzialność na nowo przywrócona twórcom i hegemonom dyskursu antropologicznego (Brocki 2011) - owym prządkom i tkaczom faktów i szczegółów (Tokarska-Bakir 2007: 10) - wymusiła przyśpieszoną refleksję nad sposobami praktykowania etnografii. Nowe czasy wymagały nowej metodologii i metodyki pracy. Zaspokojenie tej potrzeby miały zapewnić publikacje zogniskowane na samych antropologach. Wzorem Bronisława Malinowskiego (1967, 2008), Paula Rabinowa (2010) i Jeana-Paula Dumonta (1978) podążyło wielu antropologów gotowych snuć narracje o swych na poły awanturniczych przygodach (Barley 1997, 1998, 2000; Anderson 1990; DeVita 1990, 1992; Raybeck 1996). Tym sposobem, z jednej strony, wyodrębnił się nurt opowieści konfesyjnych (van Mannen 1988), na długo przypieczętowując wsobność i autoreferencyjność tego wycinka dyskursu profesjonalnego. $Z$ drugiej zaś, obok pozycji pełnych podobnych enuncjacji, zaczęły pojawiać się monografie akademickie pomyślane jako ujęcia problemowe, na kartach których autorzy starali się dostarczyć odpowiedzi na najbardziej palące kwestie związane $\mathrm{z}$ wykonywaniem pracy terenowej.

Z czasem powyższa tematyka była coraz chętniej i liczniej podejmowana, a zagadnienia odnoszące się do ciała, zmysłów, emocji, uwarunkowań politycznych, klasowych i społeczno-kulturowych samych badaczy zaczęły odgrywać coraz większe rolę. Nie powinno zatem dziwić, że na tej fali poruszano zagadnienia związane $\mathrm{z}$ wpływem długotrwałych badań terenowych na relacje rodzinne uczonych (Cassell 1987; Flinn, Marshall, Armstrong 1998), powiązania wykonywanej przez nich pracy z płcią i gender (Cesara 1982; Gold 1986; Hendry 1999) czy seksualnością (Lewin, Leap 1996; Kulick, Willson 1995; Markowitz, Ashkenazi 1999). Równie ważne stały się rozważania poświęcone roli doświadczenia $\mathrm{w}$ budowaniu wiedzy antropologicznej, prezentujące praktykę etnograficzną w jej wyjątkowym i spersonalizowanym wymiarze (Shaffir, Stebbins 1991; Fowler, Hardesty 1994; Watson 1999). Konsekwencją tej linii zainteresowania były pogłębione studia dotyczące wpływu sytuacji krytycznych czy dramatycznych doświadczeń na sposoby przeżywania i budowania wiedzy przez antropologów w stale zmieniających się warunkach terenowych (Young, Goulet 1994; McLean, Leibing 2007). Te nietradycyjne ramy teoretyczne otworzyły refleksję epistemologiczną na pozalogiczne elementy poznania, takie jak emocje (Davies, Spencer 2010) czy wiedza ucieleśniona (Hobbs, Wright 2006), stopniowo prowadząc do przemyślenia tego, czym jest i jaką winna być praktyka etnograficzna. Ostatecznie rozpoznano i zdefiniowano na nowo znaczenie i wpływ badacza na proces poznania. Dla refleksji antropologicznej stał się on zauważalny jako narzędzie 
poznania, które w znaczący sposób wpływa na kształt i charakter wiedzy (Hastrup 2008; Wyka 1996; Halstead, Hirsch, Okely 2008).

Wspomniane wątki w ostatnim czasie starała się zebrać i uporządkować Judith Okely (2012). Jej Anthropological Practice to próba przedstawienia badań terenowych i metody etnograficznej z punktu widzenia samych antropologów. W swoich rozmowach z licznymi badaczami reprezentującymi różne kręgi kulturowe Okely próbowała przedstawić drogi, które wiodły ich do wyboru antropologii, a także odsłonić przed czytelnikami arkana ich pracy i pobudki, jakimi kierowali się przy wyborze realizowanych tematów badań. Zagadnienia związane z definiowaniem terenu czy obserwacją uczestniczącą nie wyczerpują tego, czym i jaka jest antropologia, gdy się ją praktykuje. Obok klasycznych już spraw teoretycznych i metodologicznych, brytyjską badaczkę żywo interesowała zależność między pracą terenową a nabywaniem wiedzy ucieleśnionej, co z kolei bezpośrednio wiąże się z kwestią zmysłowego percypowania świata i procesu poznawania go poprzez ciało. Znamienne, że Okely w tym względzie skupiła uwagę na takich aspektach, jak płeć, wiek, rasa, wysiłek fizyczny, przyzwyczajenia, czynności i podejmowane działania czy wreszcie zmysły, spośród których wyróżniła smak i zapach. Trudno oczekiwać, by wskazane studium dało pełne spektrum praktyk etnograficznych. Refleksje formułowane $\mathrm{w}$ przytoczonym tekście stanowią pochodną jakości i rodzaju materiałów, jakimi posiłkowała się autorka.

Warto zatem zwrócić uwagę na pominięcia czy, mówiąc ściślej, te aspekty pracy terenowej, które umknęły autorce. Okely - nie sądząc jej zbyt surowo starała się przy użyciu oddolnej perspektywy samych antropologów możliwie kompleksowo przedstawić reprezentowaną przez nich dyscyplinę. To niełatwe i ze wszech miar ambitne zadanie zostało zrealizowane połowicznie w tej - na swój sposób - pionierskiej pracy. Konieczność przedstawienia punkt po punkcie elementów konstytuujących praktykę etnograficzną przesłoniła - jak się wydaje - istotę uwarunkowań, które decydują o kształcie etnograficznej władzy sądzenia. Pytając rozmówców o to, jak realizują swoje bycie jako antropolodzy, Okely nie zadała pytania nie tylko o wieloletni trening i formację profesjonalną, lecz także milczeniem pominęła charakter pola i dyskursu antropologicznego organizujących ową praktykę. W tym względzie warto sięgnąc po podpowiedzi Claudéa Lévi-Straussa, który przypominał o randze wiedzy „opartej na doświadczeniu", o myśleniu, które „ "będąc "z tego świata «, jest tej samej natury co świat” (Lévi-Strauss 2008: 55, 58), a zatem wymaga zanurzenia się w otaczającej rzeczywistości, pozostawania w ciągłym z nią kontakcie. Ta trudna, bo wymagająca wiele wysiłku, determinacji i odrobiny szczęścia sztuka, mogłaby prowadzić do prostej odpowiedzi na pytanie: jak się zostaje etnografem? Antropolog, będąc $\mathrm{w}$ terenie, wystawia się, ryzykuje własnym ciałem, oddaje się do dyspozycji badanych (Okely 2012: 1). Stopień partycypacji w codzienności obcych mu społeczności, intensywność zmysłowego w nich zanurzenia, a także skala, na jaką żyje innym (cudzym) życiem, prowadziłaby do konstatacji o szybko postępującym zacieraniu różnicy między badaczami a badanymi. Nic bardziej mylnego. 
Tym, co - zdaje się - umknęło uwadze Okely oraz wielu innych autorów piszących $\mathrm{w}$ nurcie antropologicznej metarefleksji były nie tyle same zmysły $\mathrm{i}$ ich angażowanie $\mathrm{w}$ proces poznania, ale powiązanie sensoryczności z władzą sądzenia oraz jej kulturowymi i społecznymi uwarunkowaniami. Dopiero takie rozłożenie akcentów dostarcza dobrej ramy analitycznej, która pozwala nie tylko dowodzić istnienia i działania owych struktur, ale także odsłaniać ich wpływ na dyskurs antropologiczny. Czy do tego celu potrzeba czegoś więcej niż brud? Wszak to właśnie brud w postaci nieprzyjemnego widoku, drażniącego dźwięku, złego smaku lub odpychającego zapachu najpełniej angażuje ludzkie zmysły. Brud niczym papierek lakmusowy pozwala sprawdzić, gdzie przebiega i jak daleko sięga granica możliwości poznawczych antropologa, co uwidacznia się tym bardziej w warunkach ekstremalnych, do których częstokroć można zaliczyć realia panujące podczas badań terenowych.

W kontekście „kombatanckich” opowieści o tym, z jakimi przeciwnościami przyszło się mierzyć antropologom, brud występuje raczej jako rekwizyt, element scenografii dodający koloryt światu przedstawionemu. Sam z siebie nie jest ani aktorem, ani bohaterem. Niepozorny, niechciany, uciążliwy najczęściej jest przedstawiany jako przeszkoda, z którą należy się uporać, lub wyzwanie, które trzeba pokonać. Tym samym często umyka uwadze antropologów w kontekście autorefleksji nad ich praktykami profesjonalnymi. Jego istnienie przyjmuje się za oczywiste i naturalne, podobnie jak to, że światy badanych są brudne (i może właśnie dlatego są poddawane badaniu?). Antropolog, będąc w terenie, dostrzega brud innych, w mniejszym zaś stopniu nieczystość świata reprezentowanego przez siebie. W każdym razie nie przykłada przesadnej uwagi do faktu, że kategoria ta odzwierciedla sądy estetyczne wywiedzione z jego własnej kultury. Ich istnienie uświadamia sobie $\mathrm{w}$ chwilach konfrontacji, kiedy musi mierzyć się z obrzydzeniem i wstrętem, z zahamowaniami utrudniającymi mu pracę.

\section{Brud, wstręt i odraza. Potrójny splot zainteresowania}

Jak przekonuje Mary Douglas (2007: 51), wyodrębnianie kategorii brudu, służącej do opisu nieczystości, skalania i odpadków, bierze swe źródło „z troski o higienę i szacunku dla konwencji". Brud jako resztki oraz to, co zbędne, a wręcz niepożądane (kał czy mocz), towarzyszy życiu i aktywności człowieka w wymiarze kulturowym i biologicznym od początków jego istnienia. Ów aspekt stale przekształcanego przez ludzi świata doczekał się bogatej literatury. Warto przy tym zwrócić uwagę na przeglądowe prace historyczne spod znaku Annales i nouvelle histoire, których autorzy starają się wyczerpująco przedstawić dzieje zagadnienia ujmowane z perspektywy kulturowych i społecznych przemian obyczajowości związanych z praktykami higienicznymi oraz warunkami sanitarnymi (Vigarello 1996, 2011; Ashenburg 2009), albo postrzeganiem ciała i jego miejsca w kulturze ludowej (Burke 2009; Libera 1995b, 1996, 1997, 2003). Dopełnienie tego obrazu przynoszą opracowania psychoanalityczne (Laporte 2000) oraz kulturoznawcze 
dotyczące śmieci i odpadków (Kulikowska, Obracht-Prondzyński 2015), tabu oraz wstrętu (Sztandara 2012; Werner 2014; Drzał-Sierocka, Kowalewska 2016; Czapiga, Konarska 2017), etykiety (Kowalski 2009), fizycznego czy wręcz fizjologicznego wymiaru ciała (Konarska 2011), a także tanatologii (Thomas 1991; Vovelle 2004; di Nola 2006).

Warto też zwrócić uwagę na rolę, jaką odgrywał brud jako negatywny bohater wielkich kampanii modernizacyjnych doby uprzemysłowienia, przypadającego na XIX i początek XX wieku, kiedy to nastąpił skokowy rozwój miast i zaludniających je - przeważnie napływowych - warstw społecznych. Na obecne rozumienie i traktowanie brudu wpłynęły długofalowe projekty z zakresu inżynierii społecznej, mające na celu awans szerokich mas ludzkich, a także podniesienie standardów życia, jakie przyszło im wieść w nowym środowisku. Projekty te były realizowane poprzez powoływanie i stopniowy proces specjalizacji instytucji delegowanych do rozwiązywania problemów, takich jak przestępczość, bezdomność czy szerzenie się chorób. Pojawienie się policji i więzień, opieki społecznej i przytułków, służby zdrowia i szpitali czy wreszcie sieci wodociągowych i kanalizacji, z przyświecającą im filozofią regularnych praktyk sanitarnych, służyły realizacji idei formowania członków nowoczesnego społeczeństwa, cywilizowania i kształtowania człowieka kulturalnego - przedstawiciela rodzącej się właśnie klasy średniej (Frykman, Löfgren 2007: 159-249).

Zapoczątkowana wraz z uprzemysłowieniem wieloczynnikowa socjalizacja zastępowalnych jednostek prowadzić miała do ciągłego zwiększania wydajności, przy jednoczesnym zagwarantowaniu płynnej reprodukcji coraz bardziej komplikującej się tkanki społecznej (Gellner 1991: 30-52). A zatem ten na wskroś klasowy projekt powszechnego oświecenia polegał nie tylko na bezpośrednim dyscyplinowaniu przez rygor szkolny czy środki przymusu ze strony organów władzy; implementował on również wymóg dbania o siebie rozwijany choćby $\mathrm{w}$ coraz bardziej powszechnym ruchu gimnastycznym i sporcie.

Nie był to jednak wyłączny aspekt zabiegów higienicznych (Maines 2011), których upowszechnienie wymagało rozwoju infrastruktury pozwalającej radzić sobie $\mathrm{z}$ „metabolizmem rynsztoku” (Czyżewski 2001: 119-162), czyli z odpadami i ekskrementami (Pessel 2010; Hugo 1962: 163-224). Zadanie to nie było jednak łatwe i szybkie do przeprowadzenia (Ryziński 2017: 139-140, 143-144). Do tego celu nie wystarczyły już tylko rekonfiguracje kultury czy zachowań zbiorowych (Majewski 2009), niezbędna była wizjonerska idea. Z nastaniem XX wieku dostarczył ją francuski architekt szwajcarskiego pochodzenia Le Corbusier. W 1923 roku, gdy liczyło się miasto, masa, maszyna, papież modernizmu na kartach $W$ strone architektury postulował całkowite zerwanie ze starą skorupą dotychczasowego budownictwa - wilgotnymi, ciasnymi i ciemnymi mieszkaniami sprzyjającymi szerzeniu się chorób i brudu. Jego racjonalizatorski pomysł budowania domów seryjnych był skierowany przede wszystkim do klas aktywnych społecznie. Gwarantując "nowy porządek pracy i odpoczynku” (Le Corbusier 2012: 143), miał zatem spełniać potrzeby i zaspokajać gusta, tak urzędników, intelektualistów, jak i robotników (Le Corbusier 2012: 291), a pośrednio formującej się wówczas 
klasy średniej. Częściowo godził przy tym w interesy burżuazji. W myśl tego ujęcia chodziło nie tylko o „wodę ciepłą, wodę zimną" czy poprawienie „przechowywania żywności, higienę, piękno dzięki proporcji” (Le Corbusier 2012: 137). Stawką była nowa moralność wyrażona prostą, surową i sterylną architekturą, którą przez tak projektowaną tkankę urbanistyczną chciano zaszczepić społeczeństwu. Miała zatem liczyć się nie tylko poprawa bytowa ludzi i ich zdrowia, ale przede wszystkim wkalkulowana w całe to przedsięwzięcie nowa mentalność, oparta na bardziej powściągliwej i zrównoważonej „ekonomii swoich działań, pragnień i myśli" (Le Corbusier 2012: 160) - swoistej dyscyplinie życia. Co warte podkreślenia, Le Corbusier był jednym spośród wielu wyrazicieli tendencji modernizacyjnych narastających wraz z industrializacją, a o skali i przemożności nastrojów panujących na początku XX wieku świadczyć może szybkość, łatwość i skala, z jakimi przyjęto właśnie te propozycje.

W kontrze do programów sanitarnych (i rasowych) motywowanych względami pragmatycznymi, a także fundujących je projektów odnowy życia społecznego, sytuować można zainteresowanie brudem i skaleniem płynące ze strony środowisk badających duchowość i mroczniejsze strony ludzkiej natury, w tym zjawiska religijne i sferę sacrum. Grunt pod tego rodzaju zainteresowania dały $\mathrm{z}$ jednej strony prężnie rozwijające się w XIX wieku ruchy okultystyczne i ezoteryczne (Stoczkowski 2005; Crary 2009: 92-100, 290-302; Chéroux 2014: 28-83), z drugiej zaś - naukowy, nieteologiczny namysł nad religią (religioznawstwo). W tym względzie szczególną uwagę zwraca krąg francuskich socjologów, filozofów i artystów, takich jak Georges Bataille, Roger Caillois, Pierre Klossowski czy Michel Leiris, skupionych w ramach nieformalnego Kolegium Socjologicznego, działającego pod koniec lat 30. XX wieku.

Ruch ten związany z niektórymi ideami surrealizmu, od którego wszakże odżegnywali się jego uczestnicy, kładł nacisk na społeczny wymiar aktywności człowieka związanej z seksualnością, twórczością artystyczną i estetyką, rytuałami czy kultami ofiarniczymi (Swoboda 2010; Szerszeń 2015). Dociekania prowadzone przez członków tego kręgu dotyczyły przede wszystkim tych aspektów ludzkiego doświadczenia, które w ramach życia społecznego i aktywności religijnej wiązały się z prawem zwyczajowym oraz sacrum, a także - przykładowo - upostaciowiły je: tabu, zakaz kazirodztwa, wojna i zabijanie, ekstaza, śmierć i rozkład ciała (Bataille 2009; Caillois 2009). Stąd szczególna uwaga względem wyznaczania granic i ustanawiania zakazów jako elementów konstytutywnych dla istnienia świata społecznego czy ogólniej - tego, co ludzkie, a także przemożnej potrzeby przekraczania tego, co zabronione. Transgresja bowiem, jak utrzymuje Bataille, „tworzy wraz z zakazem jedną całość, określając życie społeczne” (Bataille 2007: 69), bo oto „przekroczenie zakazu tak samo podlega regułom, jak sam zakaz" (Bataille 2007: 70). Wstręt, zgroza i odraza, mierzenie się z fizjologiczną u swych podstaw reakcją na rozmaite formy biologicznego rozkładu (krew menstruacyjną, odchody, ścierwo i trupa) stanowią granicę uczłowieczającą, dzięki której - zdaniem Batailléa - jednostka odrywa się od natury (Bataille 2008: 116). Czynnym elementem przeciwstawienia kondycji ludzkiej 
naturze - czy w węższym sensie: zwierzęcości - jest „odraza, bez której upodobnilibyśmy się do zwierząt" (Bataille 2008: 76), trwoga, która "spycha w tę samą noc funkcję seksualną i wydalniczą" (Bataille 2008: 74). Awersja, jako reakcja emocjonalna, estetyczna i fizjologiczna, pozwala "zamknąć w ciasnych granicach świat zwierzęcy cielesności" (Bataille 2008: 74), nad którym tak trudno panować.

Awersja przechodząca w obrzydzenie w jakimś sensie ma charakter skalarny, do pewnego stopnia daje się nad nią panować. Podstawą stosunku do wstrętu, jak wskazuje Bataille, jest zarazem fizyczna bliskość, bezpośredni kontakt z wydzielinami, z których „wynurzamy się z życia, z ciała, z zakrwawionego plugastwa" (Bataille 2008: 75). Z drugiej strony, istotne jest społeczne uczenie się tej postawy, gdyż

uprzywilejowanym obiektem naszego obrzydzenia jest żywa materia na tym właśnie poziomie, na którym oddzielamy się od niej. Wyciągamy nasze dzieci z brudu, potem zaś usiłujemy zetrzeć wszelkie ślady tego pochodzenia. Dokładamy starań, aby - gdy tylko osiągną wiek umożliwiający im coraz większe współuczestnictwo w naszym obrzydzeniu wobec nieczystości - wdrażać je do reagowania przerażeniem wobec wszystkiego, co emanuje z ciepłej, żywej cielesności. (...) Obrzydzenie atoli, domagające się od nas tego nieustannego odrzucenia, nie jest naturalne; przeciwnie, jego sens zawiera się w negacji natury (Bataille 2008: 75-76)².

Wstręt ma zarazem wymiar nieredukowalny - tam, gdzie dochodzi do styczności $\mathrm{z}$ trupem, odchodami i krwią menstruacyjną, awersje są niejednoznaczne (Bataille 2008: 91), a przez to mają potencjał transgresyjny.

Istota obrzydzenia, a za jej przyczyną pośrednio także istota różnic między poszczególnymi społecznościami, „tkwi w swoistościach poszczególnych grup, klas bądź pojedynczych ludzi" (Bataille 2008: 83). O tej zaś decyduje to, co przez wzgląd na brak lepszej terminologii określił Bataille jako „delikatność” (Bataille 2008: 83) czy „formę wrażliwości” (Bataille 2008: 99). Rzeczona delikatność (tak bardzo bliska dystynkcji Pierre'a Bourdieu) poprzez wysublimowanie właściwych dla poszczególnych klas „obyczajów i wyrafinowane przestrzeganie zakazów” (Bataille 2008: 83) jest niezastępowalnym czynnikiem „w dynamice klasyfikacji społecznych" (Bataille 2008: 83) - jako rodzaj wrażliwości, ekspresji a zarazem podatności. Dystans, jaki dzieli członków wewnątrz danej grupy oraz między innymi grupami, wynika - zdaniem Bataille'a - z lęku przed skalaniem i wysiłku wkładanego w ochronę przed nim, ponieważ „przestrzeganie zakazów decyduje o klasyfikacji na płaszczyźnie społecznej" (Bataille 2008: 84), a tym samym przyczynia się do zwiększenia prestiżu i umacniania stratyfikacji społecznej. Z kolei skrupulatność przestrzegania zakazów służy wyraźniejszemu odróżnieniu od innych (Bataille 2008: 86); im wyższa pozycja, tym sposób postępowania i rodzaj zapobiegliwości „nacechowany większym lękiem” (Bataille 2008: 85). Paradoksalnie $\mathrm{w}$ owych staraniach liczy się nie tyle rezultat, ile wysiłek i troska, które jako świadomie podejmowane zabiegi pozwalają oddzielić się od zwierzęcości

2 W cytatach z literatury i źródeł zachowano kursywę, jeśli była stosowana. Wszystkie inne zaznaczenia pochodzą od autora artykułu. 
(Bataille 2008: 80). W ostatecznym rozrachunku liczy się bowiem „większy dystans wobec zwierzęcości" (Bataille 2008: 86), za którym stoi fundamentalny lęk „który uczłowiecza" (Bataille 2008: 84).

Francuski intelektualista wskazuje jeszcze jedną prawidłowość związaną ze wstrętem. Chodzi mianowicie o relację względem ludów pierwotnych oraz stosunek względem warstw niższych (nędzarzy i ludzi zdegradowanych) w społeczeństwach cywilizacyjnie zaawansowanych. W pierwszym przypadku mniemanie co do własnej wyższości bierze się z przypisywania tym ludom przynależności do świata natury, sytuowania ich w obrębie tego, co dzikie i nieokiełznane; takie umiejscowienie utrudnia doszukiwanie się $\mathrm{u}$ nich podobnego poczucia obrzydliwości, które mogliby podzielać z przedstawicielami społeczeństw „cywilizowanych”. Ludy pierwotne - twierdzi Bataille - „budzą w nas wstręt, gdyż uważamy, że stoją bliżej przedmiotu naszej niechęci niż my" (Bataille 2008: 76-77). W drugim przypadku można mówić o podobnym mechanizmie różnicowania, skierowanym jednak do wewnątrz danego społeczeństwa, w którym jedni spoglądają na drugich przez pryzmat wyższości sanitarnej niedostępnej biedocie żyjącej w „ogromnym śmietnisku, paskudztwie i plugawości tak zwanych "gorszych dzielnic«" (Bataille 2008: 80-81).

Powyższe spostrzeżenie nakierowuje na trzeci dyskurs, który został powołany w rodzącym się w XIX wieku nowoczesnym społeczeństwie w celu radzenia sobie z osobliwym „,brudem” społecznym i aporią klasyfikacyjną, jakiej przysparza Inny - „dziki” pochodzący spoza cywilizowanego i chrześcijańskiego kręgu kultury europejskiej (Todorov 1996) albo odmieniec lokowany na obrzeżach rodzimej ekumeny - żebrak/dziad (Grochowski 2009; Libera 2003; Michajłowa 2010), nomada (Benedyktowicz 2000) czy szaleniec (Foucault 1987; Perzanowski 2009). Badaniem i opisywaniem takiej odmienności mieli zajmować się antropolodzy. Nie jest przypadkiem, że ta stosunkowo nowa gałąź wiedzy pojawiła się w epoce wzmożonych odkryć i ekspedycji naukowych (Burke 2016: 276-282; Stagl 1995: 233-296) jako odpowiedź na procesy ekspansji kolonialnej. Jej zadaniem było rozpoznawanie lokalnych systemów kulturowych, a przez to formułowanie opartych na porównaniach uogólnień na temat kondycji ludzkiej; pośrednio działania te przyczyniały się do dostarczania informacji o badanych ludach administracji kolonialnej. W czasach darwinizmu społecznego (Stocking 1968, 1987) antropologia została wmontowana nie tylko w system dominacji ekonomicznej i politycznej krajów europejskich nad resztą świata, ale też - wbrew założeniom jej inicjatorów (Barth 2007: 14-16) - stanowiła ideologiczne ramię cywilizacyjnego protekcjonalizmu.

Krzepnięcie nowej dyscypliny i postępująca profesjonalizacja antropologii (Jasiewicz 2011) wymagała kodyfikacji idei kluczowych dla tego pola wiedzy. Różnice stopnia rozwoju poszczególnych społeczności zamieszkujących rozmaite rejony świata sprzyjały sformułowaniu wartościującej koncepcji „społeczeństwa pierwotnego" (Kuper 2009), poprzez którą sankcjonowano nie tylko istniejące i dające się bezpośrednio obserwować różnice w poziomie rozwoju technologicznego czy cywilizacyjnego, ale też za jej pomocą legitymizowano kolejne podboje. 
Intelektualne spekulacje na temat systemów pokrewieństwa, totemizmu, różnych form kultu, krwiożerczości i kanibalizmu (Arens 2010) to fantazmaty na temat seksu i krwi. Pod deklarowanym zainteresowaniem pierwotnymi sposobami stanowienia prawa czy organizowania życia społecznego kryje się fascynacja tym, co eufemistycznie Claude Lévi-Strauss określał jako „krążenie kobiet”. Dywagacje te były uskuteczniane w zamkniętym, elitarnym kręgu światłych, szanowanych i na ogół dobrze odzianych dżentelmenów ze światowych metropolii tamtego okresu - Paryża, Londynu, Berlina, Nowego Jorku. Miały też one - jak sugeruje Adam Kuper (2009) - drugie, ukryte oblicze stanowiące rewers wiktoriańskiej pruderii. W dobie restrykcyjnej obyczajowości i etykiety działalność naukowa antropologów osłaniała erotyczne, wręcz pornograficzne fascynacje i rozmiłowanie ciałem Innego (Marcus 1985; Wieczorkiewicz 2013).

Kościec dyscypliny stanowiły zatem idee i wartości odpowiadające przede wszystkim wrażliwości dwóch warstw społecznych - mieszczaństwa oraz ugruntowującej swą pozycję burżuazji. Antropologia jako właściwa dla tego momentu dziejowego forma aktywności umysłowej, a także jako formacja dyskursywna, winna być zatem traktowana jako wytwór klasowy odpowiadający ideologii kolonializmu (a przynajmniej będący jego funkcją). Przypomnienie o takim profilu jej genezy pozwala lepiej zrozumieć swoistość antropologicznego oglądu kwestii brudu i nieczystości. „Dziki” postrzegany był nie tylko jako obiekt pedagogiki cywilizacyjnej, w ramach której antropolog pełnił rolę funkcjonariusza monitorującego ekstremalne formy życia, ale też był poddawany orientalizującemu wartościowaniu odpowiadającemu normom i estetyce właściwej kręgowi kultury zachodniej. Tym samym Inny stał się niejako elementem kluczowym dla popularyzowanego wówczas wyobrażenia o świecie, w którym biali mieli do spełnienia dziejową misję na rzecz rozwoju ludzkości, zaś „ciemne” oblicze Innego umożliwiało zwrotnie definiowanie własnej tożsamości przez Europejczyków (Maxwell 1999).

W tym względzie antropologia i rozrywka stanowiły wzajemnie przenikające i uzupełniające się formy symbolicznego oraz praktycznego przepracowania istnienia Innego. W pierwszym przypadku znaczenie miały przede wszystkim opis i klasyfikacja (Coetzee 2009: 23-51; Libera 1995a; Pratt 2011) - im to właśnie podporządkowano antropometrię (Strządała 2010; Trebunia-Staszel 2017) oraz bezpośrednio z nią powiązaną ewidencję fotograficzną typów i ras ludzkich (Edwards 2001: 131-155; Morris-Reich 2016; Lyndon 2005; Nowicki 2015: 181-211), a później także poślednich warunków życia „dzikusów” (Pinney 2011: 35-50; Ryan 1997: 155-182). W drugim przypadku wmontowanie orientalizowanego i egzotyzowanego Innego w system ludycznych atrakcji - przeradzający się stopniowo w kulturę popularną - stanowiło rezultat funkcjonowania wielowiekowych przekonań i wyobrażeń co do zwierzęcości i monstrualności obcych (Gaudio 2008; Wieczorkiewicz 2009). Te zaś zostały wykorzystane i wyolbrzymione przez propagandę kolonialną do jej partykularnych celów, związanych z uzasadnieniem kolejnych podbojów oraz eksploatacji podbitych terytoriów i zamieszkującej je ludności. 
Dogodnym narzędziem realizacji tego celu stało się przede wszystkim wystawiennictwo. Nie bez powodu organizacja wystaw światowych zbiega się z końcową fazą nowożytności i narodzinami imperiów europejskich przełomu XVIII i XIX wieku. O ile pierwszych jedenaście wystaw produktów przemysłowych organizowano w Paryżu w okresie od 1798 do 1849, o tyle dla wyznaczenia linii programowej i międzynarodowego charakteru wystaw światowych kluczowe znaczenie miała Wielka Wystawa Powszechna, zorganizowana w Kryształowym Pałacu w 1851 r. ${ }^{3} \mathrm{Na}$ jej terenie prezentowano nie tylko osiągnięcia technologiczne epoki kolei żelaznej, lecz przede wszystkim zachwalano towary i wyroby rzemieślnicze z różnych części świata. Jej organizacja sprzyjała nie tylko wolnemu przepływowi informacji i towarów, lecz również szerzeniu idei postępu. Przy okazji tej i kolejnych wystaw białej publiczności światowych metropolii starano się - wybiórczo - przybliżyć sposoby życia przedstawicieli „ludów pierwotnych”. Wystawy stanowiły żywą makietę porządku ówczesnego świata (Benedict 1983; Greenhalgh 1988; Hinsley, Wilcox 2016).

Przy okazji wystaw światowych, kolonialnych i krajowych wyodrębniono również inny rodzaj pokazów. Muzealne ekspozycje historii naturalnej miały za zadanie - za pomocą dioram wykorzystujących martwe ludzkie ciała i ich fragmenty - ilustrować stadialność rozwoju człowieka i przemiany kultury od wspólnoty pierwotnej po cywilizację (Conklin 2013; Westerman 2015). Podobną rolę spełniały wyrosłe $\mathrm{z}$ wystaw światowych i często im towarzyszące wioski i wystawy etnograficzne, które zapewniały żywą i bezpośrednią - namacalną, wizualną, audialną, proksemiczną i zapachową - obecność Innego, a przez to przybliżały publiczności prymitywne, wręcz odrażające warunki życia „dzikusów" i ich okrutne zwyczaje (Coombes 1994: 129-160; Parezo, Fowler 2007; Qureshi 2011). Podobne inscenizacje organizowano początkowo w celach edukacyjnych albo ideologicznych, by podkreślić różnice i wyższość rasową (Brownell 2008; Hoffenberg 2001), później również komercyjnie (Lindfors 1999). Część wystaw etnograficznych miała za zadanie propagowanie rzemiosł wiejskich dla znalezienia nowych rynków zbytu dla przemysłu ludowego, co miało ekonomicznie wspomóc chłopstwo (Puchta 2016; Turkawski 1880), częściej jednak wioski etnograficzne i ludzkie zoo jako źródło rozrywki dla miejskiej gawiedzi stanowiły przede wszystkim źródło zysków dla przedsiębiorców stojących za ich organizacją (Blanchard i in. 2008; Blanchard, Boëtsch, Snoep 2011; Rothfels, 2002: 81-142, 195-196).

W tym kontekście teoria antropologiczna, pozostająca $\mathrm{w}$ bezpośrednim związku z procesami kulturowymi zachodzącymi w społeczeństwach zachodnich, stanowi nie tylko wyraz panujących w XIX i XX wieku prądów intelektualnych, ale przede wszystkim może być postrzegana jako wyraz swoistego wartościowania ludów obcych temu kręgowi kulturowemu. Mając na uwadze wskazane trzy uwarunkowania wpływające na wyodrębnienie brudu jako

Był to też rok, w którym, przy okazji Wielkiej Wystawy, na szeroką skalę zaczęto propagować korzystanie z muszli klozetowej i systemu urządzeń sanitarnych wykorzystujących wodę. 


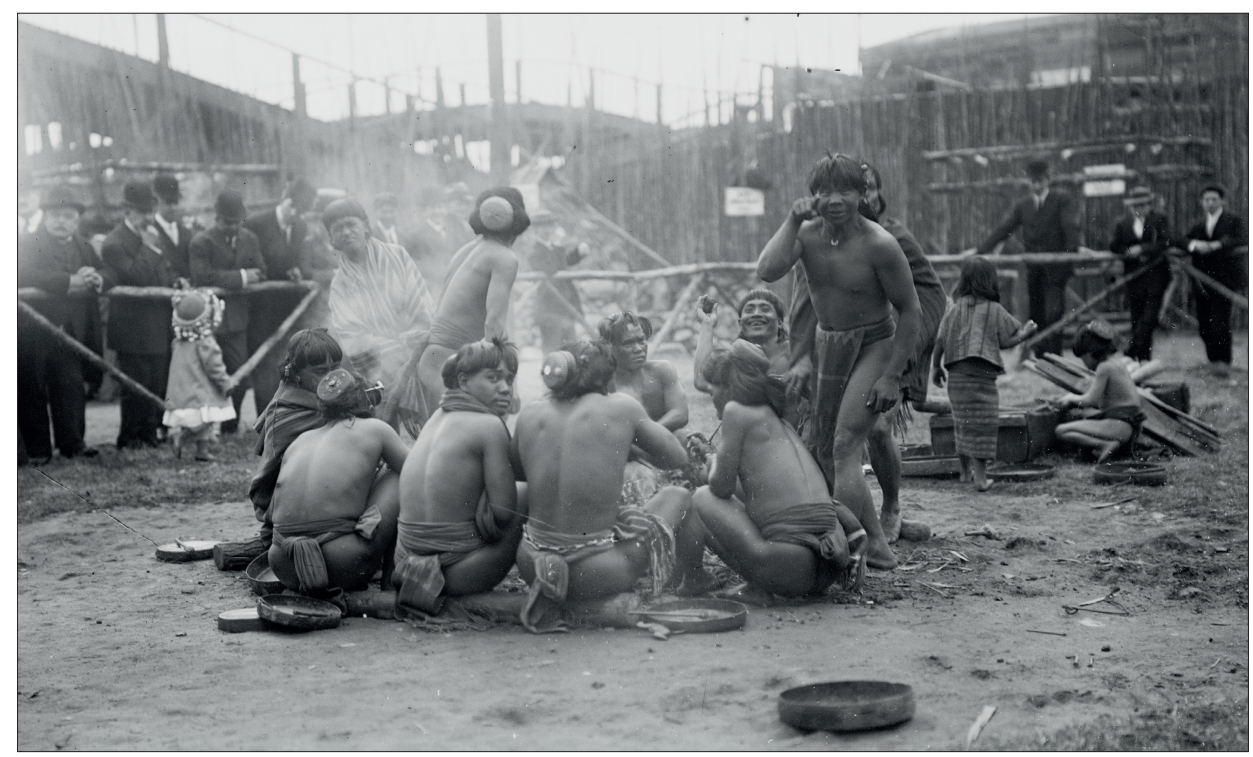

Fot. 1. Kuso ubrani Filipińczycy siedzący w kręgu w parku rozrywki Dreamland, Coney Island, Nowy Jork, lipiec 1905

Igoroci zostali sprowadzeni do Stanów Zjednoczonych przez Departament Wojny we współpracy z prywatnym przedsiębiorstwem Lewis \& Clark Centennial Exposition w Portland (1905) na potrzeby Wystawy światowej zorganizowanej w Saint Louis w 1904 r. Przedstawiciele tego plemienia byli następnie prezentowani w Dreamlandzie na Coney Island (1905), a także podczas Wystawy światowej Alaska-Yukon-Pacific w Seattle (1909). Ich obecność miała charakter propagandowy i legitymizowała ekspansję terytorialną Stanów Zjednoczonych na obszarze Pacyfiku. Pokazy życia codziennego i „pierwotności” tego i innych ludów tubylczych organizowano na terenie Ameryki Północnej i Europy w celach edukacyjnych, jak również rozrywkowych podczas wystaw światowych lub krajowych, wystaw etnograficznych, w ramach działalności cyrków (w tym pokazów dziwolągów), parków rozrywki, a także ogrodów zoologicznych.

Źródło: Bain News Service (Library of Congress, George Grantham Bain Collection, LC-DIG-ggbain-03959)

społecznie konstruowanej kategorii opisu, warto przyjrzeć się, w jaki sposób była ona wykorzystywana wobec chłopów przez polskich etnografów podczas prowadzonych przez nich badań.

\section{Wizytatorzy nędzy, kolekcjonerzy wrażeń: brud Innego}

Brud i reakcja odrazy stanowią jeden z elementów wyróżniających w narracjach na temat Innego. Odmienność zachowań, osobliwość wyglądu i mowy oraz podejście do kwestii czystości częstokroć różne od tego, co przyjęte za normę w ramach kultury opisującego, stanowią łatwo dające się uchwycić wyznaczniki różnicy między tubylcami a przybyszami, między badanymi a antropologami.

Traktując brud jako wyróżnik deskryptywny, warto uważniej przyjrzeć się temu, jak jego ogląd kształtuje się wśród antropologów - owych zawodowych 
znawców dziwności. Jak przekonuje Julia Kristeva, wstręt, choć uniwersalny, jako zjawisko przybiera różne formy - zmienne zarówno pod względem historycznym oraz społecznym; wreszcie ,jest [on] odpowiednikiem porządku społecznego i symbolicznego na skalę indywidualną i zbiorową" (Kristeva 2007: 67). By przekonać się, jakie formy brudu są specyficzne dla „kultury profesjonalnej etnologów" (Brocki, Górny, Kuligowski 2006), należy sięgnąć po kilka przykładów, które odsłonią odmienne acz powiązane ze sobą aspekty obrzydzenia ujawniające się bardziej lub mniej otwarcie w trakcie badań terenowych.

Grupa polskich etnografów pod kierownictwem Anny Kowalskiej-Lewickiej podjęła się w latach 50 . minionego wieku badań rolnictwa, hodowli i rzemiosła na terenie Podhala. Prace terenowe były prowadzone od 1951 do 1955 roku, choć największe ich natężenie przypadło na lata 1952-1953. W zamyśle organizatorki przedsięwzięcia członkowie zespołu prócz wywiadów mieli prowadzić ",naoczną obserwację życia wsi i zabiegów gospodarskich"; dla poznania "cyklu rocznego tego życia i zabiegów” konieczne było "przebywanie na wsi w różnych porach roku" (Kowalska-Lewicka 1958: 249, 251). W trakcie tak pomyślanych badań i wielokrotnych powrotów do tych samych wsi etnografowie towarzyszyli wybranym rodzinom, co pozwalało im zbliżyć się do nich i lepiej poznać mentalność chłopów. Do rejestrowania obserwacji służyły dzienniki badawcze, w których należało odnotowywać „,wszelkie obserwacje, celowe lub robione przy padkowo, dotyczące całokształtu życia wsi i prowadzenia badań terenowych, gdzie wreszcie znalazły swe miejsce wszelkie refleksje badacza i pierwsze próby uogólnieńn (Kowalska-Lewicka 1958: 252-253).

Ze wspomnianych badań zachowało się bardzo wiele takich dzienników, które obecnie znajdują się w zasobach Ośrodka Dokumentacji i Informacji Etnograficznej PTL w Łodzi. W przypadkowo wybranych dwóch dziennikach opisujących tok etnograficznych badań terenowych prowadzonych w Obidowej od 7 do 14 lutego 1953 roku natrafić można na następujące zapisy dotyczące praktyk higienicznych:

Wszystkie niemowlęta leżą tu w kołyskach na biegunach, w których na dnie wywiercone są dziury przez które wypływa mocz (AKL: 10).

Dziaduś jest strasznie miły, ma dobroduszny, żartobliwy wyraz twarzy. (...) Całym jego zajęciem, które wykonuje w czasie mojej obecności jest kołysanie Marysi i trzymanie jej na kolanach. Podkłada jej przytem szmatkę z kołyski. Kiedy dziewuszka załatwi się na podłoge - wyciera się to najspokojniej w świecie (EK: 19).

W notatkach poruszane są również wątki dotyczące panującego brudu i mizerii:

Dziadek mieszka w jednej izbie z córką i wnukami. Córka wyszła za gazdę, który ma dom niżej nad potokiem, bo dom dziadka leży na stromej górce, i gazduje trochę z mężem a trochę z ojcem. W izbie leży cielę w kałuży moczu i kału, 
kręci się wnuczka mw. dwuletnia [w] straszliwie brudnej sukience i śmierdząca świeżym kałem. Brud straszny! (AKL: 16).

Cielę, które było wczoraj w izbie, zarżnięto, bo nie chciało pić (EK: 8).

Kiedy weszliśmy, ona skrobała grule, on łatał coś, co leży na podłodze, a co kiedyś było prawdopodobnie serdakiem - teraz same dziury i łaty. Gazda porusza się powoli, kuleje, mówi z trudnościami, kaszle, „dusi go". (...) Nie chodzą do kościoła, bo nie ma się w co ubrać, a zresztą on ledwie wlecze nogą. (...) Wychodzimy przybici panującą biedą i tym, że przez kilka godzin nie posunęliśmy się w pracy (EK: 4-5).

Tropy dotyczące wielozmysłowego doświadczania rzeczywistości polskiej wsi warto wzbogacić jeszcze jednym wspomnieniem - odnoszącym się do zupełnie innych badań z lat 70. minionego stulecia - które mówi równie wiele o podejściu ówczesnych etnografów do kwestii czystości i jej braku:

Trzeba przełamać pewną barierę i do obcego człowieka podejść, zaczepić, starać się właśnie tutaj jednak go zjednać dla siebie i do tej rozmowy. To niemniej, tak jakoś, takie kłopoty, że [koledzy] jak mogli unikali, więc dlatego badania terenowe były dla nich na pewno, no jakąś męczarnią. I potem to wychodziło, na przykład, już przy jakichś opracowaniach (...). Innym wieś śmierdziała. Jakoś się tego nie spodziewali, że to też są różne zapachy, odcienie - prawdziwa wieś: i gnojowisko, różne nieraz, i brud w izbie, nieraz skaczące pchły. [Śmiech.] Należę do osób, które właśnie, jeśli gdzieś coś jest, to mnie opadnie. Jak to mówią, żartują, że jak ktoś ma słodką krew... - Tak się dawniej mówiło. - No więc też się tego troszkę boję. Kiedyś, pamiętam, bo braliśmy udział - kto chciał, to wtenczas miał zniesioną praktykę czy skróconą praktykę - w badaniach Rudawy. Siedziałam właśnie u takiej babci; no, mizernie tam miała. Wiem, że zimą ja byłam ubrana w jakimś tam futerku, ona nie paliła. Straszna mizeria taka była, była samotna. Ale tak... Usłyszałam w pewnym momencie - po tej niezagrzanej blasze od pieca, że coś pyka. Pyk, pyk, pyk. - Zawsze miałam dobry słuch, teraz gorszy. - Ja tak patrzę na blachę i zesztywniałam. Po tej blasze skakały pchły. I tak, że było słychać: pyk, pyk, pyk. No to sobie pomyślałam: ,ja w tym futerku, to ja to wszystko przeniosę". No ale musiałam dokończyć rozmowę i nic oczywiście nie mówiłam, bo takie miała warunki, jakie miała. Ale rzeczywiście był problem, ale jakoś taka nie byłam - żartuję - obrzydliwa. W sensie, że mnie coś tak obrzydzało czy zrażało. Rozumiałam, że tak może nie musi być, ale że tak bywa, bo wiadomo, że blisko jest gospodarstwo, może być jakieś tam: czy świnki hodowane, więc chlewnia; czy bydło, więc są takie zapachy wsi i... Natomiast, niektórzy mieli taka bariere, że owszem spaliny w każdych ilościach, ale zapach wsi - to nie (2010/008/B).

Przywołane fragmenty notatek terenowych oraz ustna relacja złożona po czterdziestu latach od opisywanej sytuacji odsłaniają ambiwalencję podejścia etnografów do brudu i higieny. Nie dowiadujemy się z nich, czy i - ewentualnie jaką wagę do podobnych kwestii przykładali żyjący w opisany sposób ludzie? Czyj stosunek do brudu i sposoby jego doświadczania - kategoryzowania, 
wyróżniania, działania nim powodowane - zostają opisane w tych fragmentach? Czyje jest to obrzydzenie? Choć wstręt nie zostaje tu wyartykułowany wprost, to jest obecny omownie - jako „to", co się wylewa, co wzbudza zgrozę, politowanie lub co etnograf winien heroicznie znosić jako niedogodność podczas pracy, w ten sposób doskonaląc się oraz ćwicząc siłę woli i samokontrolę. Wstręt ujawnia się przez niedyskrecję tych, o postawach których mówi najwięcej. Warto zastanowić się, dlaczego w notatkach czy opowieściach o pracy terenowej pojawiają się podobne spostrzeżenia - dużo liczniejsze aniżeli przywołane przykłady - o pchłach, robakach, pasożytach, zepsutym jedzeniu, smrodzie i rozkładzie czy wreszcie środkach mających zaradzić tym niedogodnościom, choćby własnych śpiworach czy prześcieradłach zszytych tak, aby ograniczyć kontakt ciała z pościelą, w której wcześniej sypiali chłopi (Kopczyńska-Jaworska 2000: 52-53; Szyfer 2006: 54, 64).

Odnosząc ogólne ustalenia Kristevy do kwestii warunków pracy etnografów, brud, z którym bezpośrednio się stykali, wyznaczał granicę tych dwóch światów - badanych i badających. Jego obecność $\mathrm{w}$ terenie, a przede wszystkim widoczność w polu uwagi, wraz z mniej lub bardziej otwartymi reakcjami odrazy ze strony etnografów, zdradza "obiektywną kruchość porządku symbolicznego" (Kristeva 2007: 69) kultury, której byli emisariuszami. A zatem reżimu higienicznego, który reprezentowali. Brud to bolesne ukłucie wizy towanej rzeczywistości wrażone $\mathrm{w}$ delikatne i podatne ciało antropologa - to amorficzna przeszkoda i wyzwanie rzucone dyscyplinie badaczy. Niektóre

rzeczy w świecie Terenu zdają się być „wyraźnie nie na swoim miejscu” (...), a to przejmuje lękiem i zmusza do działania zabezpieczającego przed domniemanym destrukcyjnym wpływem. Teren może zarazić fizycznie, ale i duchowo. Wyznaczane są zatem granice, a to, co one wydzielają i dookreślają, poddawane jest systematycznemu oglądowi. Teren jest terenem właśnie dlatego, aby mógł być kontrolowany (Żerkowski 2015: 157-158).

W końcu - jak przekonuje Michel Foucault (1998: 205) - dyscyplina to technika służąca produkcji użytecznych jednostek. A takimi w terenie mieli być etnografowie (Wróblewski 2015: 336-340, 2016: 161-169).

Przedstawione reakcje, choć wydają się spontaniczne, w istocie stanowią realizację kulturowo warunkowanego wzorca zachowania dostępnego dzięki "wiedzy cielesnej wpajanej jako podzielane kulturowo dyspozycje" (Csordas 1990: 20). Dokonywane w terenie rozpoznanie higieniczne wiąże się z przywołaniem i uruchomieniem określonego porządku wartościowania, ten zaś jest ściśle powiązany z ucieleśnionym $\mathrm{i}$ warunkowanym klasowo cielesnym aparatem awersji, który obejmuje wzorce przeżywania, w tym odruchy oraz mikroekspresje wzdraganie się, przełykanie śliny, grymasy twarzy, odsuwanie się i wiele innych. Wprawdzie nie dowiadujemy się o nich z tekstu, lecz domyślnie i nieuchwytnie towarzyszą one narracji. Tekst nie tylko pośrednio odnosi się do tych reakcji, lecz również wywołuje je w czytelniku. Dzieje się tak za sprawą ,"schematów percepcji i oceniania" (Bourdieu 2005: 29) podzielanych przez członków danej wspólnoty 




Fot. 2. Badania terenowe

Fotografia wykonana w trakcie badań terenowych. Badaczki usiadły w cieniu przed stodołą, obok przy bielonej ścianie chałupy stoi rodzina chłopska. Zdjęcie, w dyskretny sposób, dokumentuje różnice klasowe i dystans międzygrupowy. Wyraża się on w nieznacznym oddaleniu jednych od drugich, a także odmiennych postawach ciała i zachowaniach. Dystynkcję etnografek podkreśla krój sukienek odpowiadający miejskim wzorom mody, a także obuwie i białe skarpety kontrastujące z bosymi, utytłanymi stopami mieszkańców gospodarstwa.

Źródło: Fot. M. Gładysz (ze zdjęć udostępnionych Instytutowi Etnologii i Antropologii Kulturowej Uniwersytetu Jagiellońskiego)

(w omawianym przypadku przesądza o tym przynależność do kultury profesjonalnej etnologów). Sposób społecznej organizacji grup oraz łączące ich członków wyobrażenia, wartości i działania - pomijając czysto fizjologiczny aspekt reakcji - miały bezpośredni wpływ na to, co ustanawiano przedmiotem odrazy, a także na to, jak winno się ją okazywać. W tym sensie wstręt przybiera zmienne w czasie „specyficzne formy, różne sposoby kodowania zgodne z odmiennymi "systemami symbolicznymi«" (Kristeva 2007: 67).

Wstręt żywiony przez etnografów stanowi pochodną formacji dyskursywnej stojącej u podstaw antropologii jako dyscypliny naukowej. Ta zaś jako wytwór klasowy w wymiarze aksjonormatywnym odpowiada wrażliwości i moralności mieszczańskiej, w szczególności zaś ideologii związanej z aktywnością tej warstwy społecznej. W polskich warunkach prekursorami ludoznawstwa byli literaci, dziennikarze, urzędnicy, księża, wiejscy nauczyciele, ziemianie (Libera 1995a: 140; Jasiewicz 2011) oraz inteligencja rekrutująca się z kręgów miejskich, jak również szlacheckich. W przeważającej mierze byli oni „nosicielami światopoglądu klas wyższych i kultury elitarnej" (Węglarz 1994: 88). Ten właśnie 
"szlachecki rodowód polskiej inteligencji” w szczególności „sprzyjał transmisji starych stereotypów i mitów społecznych" (Libera 1995a: 141), mając przełożenie na kształtowanie, utrwalanie i upowszechnianie wyobrażeń zbiorowych na temat ludu. Oznaką takiego stanu rzeczy był przede wszystkim dystans i protekcjonalizm wobec "obcego" (klasowo ludu) - jednocześnie starannie przy tym maskowany w dyskursie antropologicznym (Libera 1995a: 141). Obcość kulturowa ludoznawców - a później etnografów - względem warstwy chłopskiej (Węglarz 1994: 89) sprzyjała długotrwałemu utrzymywaniu się jednostronnego „wyobrażenia o ludzie i jego kulturze" (Węglarz 1994: 84) ukształtowanego w zgodzie z obecną także w okresie PRL „ideologią ludoznawczą" (Węglarz 1994: 85, 87, 94, 96). Jej istotą była ambiwalentna konceptualizacja chłopstwa traktowanego raz jako siedlisko zabobonów i zacofania wymagające reformy, innym razem uznawanego za rezerwuar kulturowego autentyzmu i wartości narodowych podlegających szczególnej ochronie ze strony badaczy. Taka ideologia - przepajająca również profesjonalną etnografię XX wieku - miała wpływ na zachowanie uprzywilejowanej pozycji oraz dostępu etnografów do kształtowania dyskursu na temat chłopów. Wszak antropologia jest tak zorganizowana po dziś dzień, że jej badanym „przedmiotem są przecież kultury różne od »podmiotowej« kultury danego badacza" (Węglarz 1994: 84).

Znamiona paternalistycznego pozycjonowania „przedmiotu” badań znaleźć można w interwencyjnym piśmiennictwie na temat ubóstwa wsi i społecznych skutków emigracji. Obrosła legendą - zasłużoną, gdy idzie o postulaty i wskazania należytego traktowania ludzi w trakcie badań terenowych - idealistyczna Społeczność wiejska, została napisana na zlecenie Instytutu Gospodarstwa Społecznego. Kazimierę Zawistowicz-Adamską - autorkę tego opracowania interesował w pierwszej kolejności stan majątkowy danej rodziny, a następnie wpływ, jaki na jej strukturę wywarła emigracja (Zawistowicz-Adamska 1948: 13). Dając literacki opis położenia i warunków zubożałego chłopstwa żyjącego na prowincji, etnograf zwracała uwagę na niedolę losu komorników, wyrobników i nędzarzy. Próbki „społecznikowskiego zacięcia” - ocenianego współcześnie z mieszanymi uczuciami (Kaniowska 2011: 125-126, 2013, 2014) - widać choćby $\mathrm{w}$ dwóch poruszających fragmentach poświęconych wykluczeniu ze społeczności wskutek narodzin nieślubnego dziecka (Zawistowicz-Adamska 1948: 52-55) czy desperacji starej kobiety powodowanej ustawicznym głodem, która by leczyć problemy żołądkowe, za cudzą radą zaczęła pić gnojówkę (Zawistowicz-Adamska 1948: 50-52). W tym względzie znamienna jest reakcja badaczki na opowiadaną ze łkaniem i dygotem historię:

Robi mi się mdło. Zatrzymuję oddech, by nie wdychać zaduchu. W uszach szum. (...) Odchodzę stamtąd późnym wieczorem. Po wyjściu z dusznej izby z trudem łapię oddech. Zachłystuję się mroźnym powietrzem. Jestem przeziębnięta do szpiku kości, obolała i odurzona. Z doznanych wrażeń, czy ze zmęczenia. W plecach doskwiera nieznośny ból (Zawistowicz-Adamska 1948: 51). 
Zasadniczą cielesną reakcją Zawistowicz-Adamskiej jest fizjologiczna $\mathrm{w}$ odruchach ucieczka. Tak jakby wdychanie tego samego powietrza co badani mogło ją skazić. Doświadczany zmysłowo „zapach kopciu, połączony z kwaśnym zaduchem izby" (Zawistowicz-Adamska 1948: 50-51) oraz wszelkie odczucia związane z innymi bodźcami płynącymi zarówno z przebywania w tym miejscu, jak również powodowane wyobraźnią - uruchomione tak przez zasłyszaną opowieść, jak i wiedzę na temat stanu higieny w badanej wsi - stanowią podstawę do budowania dystansu etnografa. Jej człowieczeństwo wprawdzie „ugina się pod brzemieniem niedoli przytłaczającym tamto istnienie" (Zawistowicz-Adamska 1948: 52), a ona sama niesie - czego jest w pełni świadoma - znikomą pomoc bliźnim. Niemniej kobieta z wdzięczności obejmuje ją, czepia się rąk i nóg, a zażenowanej badaczce jest „nieznośnie przykro" $\mathrm{i}$ „,z trudem wyzwala się z jej objęć" (Zawistowicz-Adamska 1948: 52). Jej ciało nie musi już dotykać „okropnych szmat" (Zawistowicz-Adamska 1948: 51). Trudno, by wskazane reakcje były inne. Za to, w kontekście idei głoszonych przez Zawistowicz, znaczący jest gest odsunięcia się, wstrzymanie oddechu - ucieleśniona odmowa wspólnego „przeżycia” trudnego położenia. To nieuświadomiona (?) odraza przed skalaniem, które

jest tym, co wypada z „systemu symbolicznego". Jest tym, co wymyka się społecznej racjonalności, logicznemu ładowi, na którym zasadza się społeczeństwo jako całość i które wówczas zaczyna się odróżniać od tymczasowego konglomeratu jednostek, aby w końcu utworzyć system klasyfikacji albo strukturę (Kristeva 2007: 65).

A przecież omówione zdarzenie oraz jego rozumienie zasadzają się na „nierównej relacji klasowej" (Mokrzan 2011: 138) zdiagnozowanej przez Michała Mokrzana przy okazji demistyfikacji środków perswazji użytych na kartach Społeczności wiejskiej. Na kwestię tę zwracała uwagę także Grażyna Kubica, akcentując fakt, że Zawistowicz traktowano we wsi jako miastową, ,jako "paniąu, członkinię wyższej klasy, czyli dominanta" (Kubica 2018: 169). Tym samym ujawnia się immanentna cecha dyskursu antropologicznego związanego ze swoistą pedagogiką społeczną i władzą pastoralną, które polegają nie tylko na wskazanym uprzednio uprzywilejowaniu w tworzeniu reprezentacji, ale też uprawnieniu do mieszania się w cudze sprawy. Jak mimowolnie pokazała Zawistowicz-Adamska, w obrębie omawianego dyskursu liczy się przede wszystkim smak, wyrobienie i osąd etnografów, właściwe tej grupie profesjonalnej poczucie estetyki powiązane z etyką. W dobie, gdy mechanizmy władzy „zawładnęły ciałami, gestami i zachowaniami" (Foucault 2013: 352), antropologia - jako jedna z wielu humanistycznych dyscyplin dostarczających wiedzy poprzez „wielki wysiłek dyscyplinowania i normalizacji” (Foucualt 2013: 352), a tym samym składających się na rozproszony aparat władzy - poprzez klasową i społeczną wyższość upoważnia swych przedstawicieli do kontrolowania innych. Antropologia jako pochodna działań filantropijnych - wszak w zamyśle fundatorów miała służyć ochronie ludów tubylczych - w pisuje się w długotrwały proces budowania instytucji, które 
zaczynają wtrącać się w życie innych, w ich zdrowie, w to, co jedzą, jak mieszkają... Następnie z tej niejasnej funkcji wyłaniają się postaci, instytucje, nowe dziedziny wiedzy... higiena publiczna, inspektorzy, asystentki społeczne, psychologowie (Foucualt 2013: 353).

Nie dziwi zatem intelektualna bliskość etnograf Zawistowicz-Adamskiej z Heleną Radlińską - twórczynią polskiej szkoły pedagogiki społecznej i założycielką wydawnictwa Polskiego Instytutu Służby Społecznej, dzięki któremu ukazała się Społeczność wiejska (Kamiński 1967; Kafar, Kamińska-Jatczak 2017).

Wreszcie, tożsamość dyscypliny definiowana wobec i za pomocą „przedmiotu" badań zasadza się przede wszystkim na różnicy od niego, a także podtrzymywaniu jej zarówno w wymiarze dyskursywnym, jak i przez zestandaryzowane działania i indywidualne praktyki. Doskonałym operatorem służącym do wyrażenia tego stosunku oraz - co za tym idzie - podtrzymania przepaści między klasami była i jest kategoria brudu. Wiąże się ona zarówno ze sposobami ujmowania i przedstawiania świata, jak również dostarcza wzorców jego doświadczania.

Echa takiego stanu rzeczy można łatwo znaleźć w piśmiennictwie etnograficznym. Zbigniew Libera zwracał uwagę, że opis tworzony przez badaczy na potrzeby reprezentacji mieszkańców wsi to nic innego jak „,wyraz skonwencjonalizowanego "miejskiego gadania " na temat chłopa" (Libera 1995a: 137). W dodatku opis ten nie jest wolny od przedsądów i wyobrażeń projektowanych na chłopów, organizują go bowiem nałożone nań „,siatki wyjaśnień, motywacji, komentarzy, ocen moralnych i estetycznych" (Libera 1995a: 143). Nie dziwi zatem, że zainteresowanie ludem znajdowało dotychczas uzasadnienie przede wszystkim we względach społecznych, ekonomicznych i politycznych, przesłanianych motywacjami naukowymi i - co nie mniej ważne - estetycznymi (Węglarz 1994: 87). Jedną z klisz rzutowanych na całokształt życia i kultury wsi był obraz jej sielskości i swojskości (Libera 1995a: 146). Co ważne, był on nie tylko specyficzny dla gatunków literackich wykorzystywanych przez ludoznawców w XIX wieku, ale także znalazł swe przedłużenie $w$ etnograficznych enuncjacjach i eksploracjach idealizujących sztukę ludową, folklor, strój, architekturę drewnianą czy tradycyjne wzornictwo (Kordjak 2016; Korduba 2013). Jak konkludował Zbigniew Benedyktowicz, podobne prezentacje dawały zniekształcony, zafałszowany "obraz wsi polskiej pozbawionej nędzy, brudu, pijaństwa - a to właśnie ten obraz kojarzono powszechnie z wytańczonym i wyśpiewanym ludem à la Kolberg" (Benedyktowicz, Czaja 2014: 7).

W terenowych inskrypcjach etnografów można natrafić na opisy różne co do jakości, szczegółowości i podejmowanej tematyki. Przykładowo, Ewa Kamińska - uczestnicząc $w$ badaniach podhalańskich zainicjowanych przez Kowalską-Lewicką - obserwowała intymną scenę, której plastyczny i nad wyraz sensualny opis dała w swoim dzienniku:

Patrzę jak młoda jeszcze kobieta, po której widać już pięcioro urodzonych $\mathrm{i}$ „odchowanych” dzieci siedzi bokiem na kołysce. Widzę ją z profilu. Na pierwszym planie ściana kołyski z krągło, ale niezdarnie zarysowanymi biegunami. Z kołyski wygląda poduszka w kratkę, trochę niedopięta: widać czerwoną 


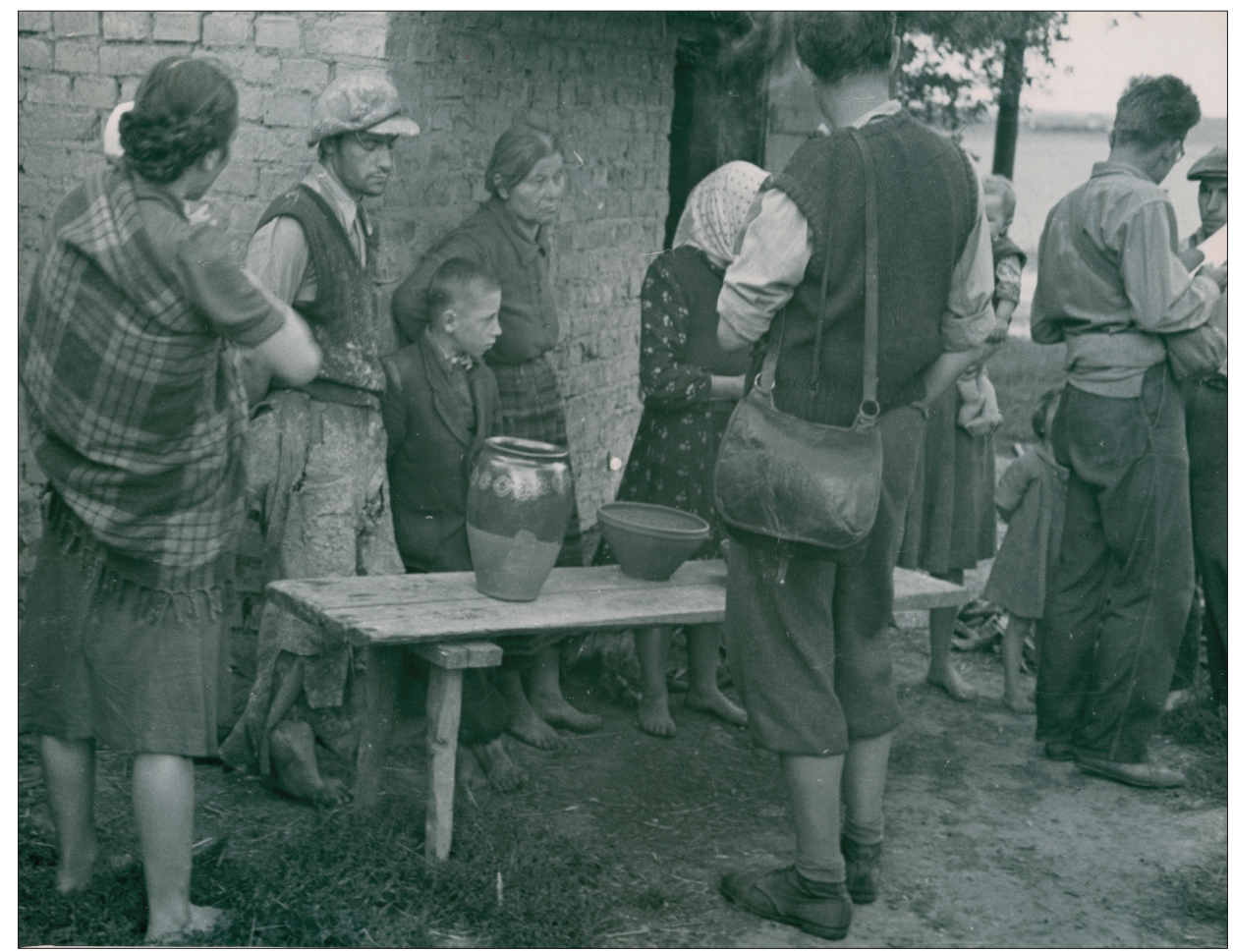

Fot. 3. Wywiad u garncarza, Glinne pow. Łuków, 1954

Zespół etnografów w trakcie prowadzenia badań z zakresu dokumentacji plastyki ludowej. Etnografowie (plecami do fotografującego, na pierwszym planie) prowadzą wywiady z rzemieślnikami i członkami ich rodzin (na drugim planie). Obie grupy stoją naprzeciw siebie. Tym, co wyróżnia ich członków jest ubiór i sposób zachowania. Chłopi wydają się bierni i wycofani, wrażenie to wzmacnia postawa ciał części z nich - ze spuszczonym wzrokiem opierają się o ścianę. Ich ubiór nie jest tak staranny i schludny jak w przy padku badaczy.

Źródło: Fot. T. Kaźmierski (Muzeum Etnograficzne im. Seweryna Udzieli w Krakowie, Kolekcja ISPAN, nr inw. L/15.504)

podszewkę. Kobieta lewą ręką /od mojej strony/ przytrzymuje niemowlę prawą podaje mu pierś, wysuniętą dołem spod luźnej bluzki. - widać tylko palce i pierś. Gaździna jest bez chustki, jeden warkocz, niedbale spleciony zakończony białą tasiemką, zsunięty na prawe ramię. Pochylona miękka, krągła szyja, na twarzy uśmiech matki. Patrzę na nią trochę z przodu i z boku. Lekko pochylona nad dzieckiem, które owinięte jest ciasno w białe powijaki główką ułożone w moją stronę. Włoski i twarzyczka odcinają się na białym tle. Bose nogi kobiety nie sięgają do podłogi. Żółtawe światło naftowej lampki (EK: 13-14).

Obraz, który wyłania się z tego tekstu, nie tylko inkarnuje literacki topos Matki Polki, sytuując go w postaci góralki karmiącej dziecko, lecz również wskazuje skalę estetyzacji, na jaką pozwalali sobie etnografowie. Była ona związana przede wszystkim z kapitałem symbolicznym, jakim dysponowali - ich wyrobieniem intelektualnym i kulturalnym nabytym w procesie edukacji. Niemniej 
równie ważne w tym względzie okazują się zainteresowania, uzdolnienia oraz indywidualna wrażliwość.

Badacze w terenie nie byli wolni od wzorców i klisz estetycznych, które przyswoili podczas akulturacji i socjalizacji profesjonalnej. To one - warunkowane kulturowo i klasowo jako dystynkcja - uruchamiały swoiste postrzeganie rzeczywistości, organizując percepcję zmysłową wsi przez przybyszy z miasta. Jak swego czasu przekonywał Dariusz Czaja, śledzący artystyczny wymiar pisarstwa Bronisława Malinowskiego i Claude’a Lévi-Straussa na przykładzie Dziennika i Smutku tropików (za to z pominięciem wpływu uwarunkowań klasowych i formacji dyskursywnych), „doświadczenie etnograficzne zawiera w sobie, jako warunek konieczny, doświadczenie estetyczne" (Czaja 2000: 395). Liczne ślady przenikania się terenowych praktyk badawczych z uwewnętrznionymi, ucieleśnionymi schematami poznawczymi tej proweniencji znaleźć można w kolejnych notatkach:

Gdy szłam do Cupty, około g. 10, sunęły całe rzędy gnatek zaprzężonych w konie i woły do lasu po drewno. Koło godz. 3 - 4 wracają ciągnąc pnie drzewne. Wożą drewno z lasów własnych i lasów gromadzkich. Wspaniały śnieg i trzaskający mróz ułatwia im zwózkę po bezdrożach, a raczej po drogach, które są czasem o wiele gorsze od bezdroży (AKL: 4).

(...) korzystając z słonecznej pogody sfotografowałam woły wożące gnój na pola. Chłopcy pędzący woły sami zaproponowali że sanie obrócą do słońca i zadali sobie dużo trudu, żeby nawrócić w głębokim śniegu (AKL: 6).

Obecność fotografii - medium służącego zarówno dokumentacji, jak i twórczości artystycznej - zdradza nie tylko znajomość kanonów piękna i reguł jego oceny, ale też wskazuje na ich świadome poszukiwanie w otoczeniu. Tę predylekcję widać też w bezproduktywnych z punktu widzenia chłopów działaniach etnografów, którzy w trakcie prowadzenia badań poszukiwali także spokoju na łonie przyrody, realizując w ten sposób praktyki typowe dla ruchu krajoznawczego i turystycznego. W końcu w grze o status społeczny „dyspozycja estetyczna wszelako stanowi także dystynktywny wyraz uprzywilejowanej pozycji w przestrzeni społecznej” (Bourdieu 2005: 74). A poprzez tak „ostentacyjne” celebrowanie szlachectwa kulturowego, na jakie pozwalali sobie etnografowie, uprawomocniali właściwe reprezentowanej przez siebie klasie „roszczenia do »naturalnej dystynkcji«jako absolutyzacji różnicy” (Bourdieu 2005: 76). Jako obcy w środowisku wiejskim musieli obnosić się z własną odmiennością, ponieważ jak sugeruje Pierre Bourdieu -

jawne wybory estetyczne dokonywane są bowiem najczęściej w opozycji do wyborów grup znajdujących się najbliżej w przestrzeni społecznej, z którymi konkurencja jest prawdopodobnie natychmiastowa i najbardziej bezpośrednia, oraz - ściślej biorąc - w odniesieniu do tych wyborów, w których najlepiej zaznacza się postrzegana jako uroszczenie intencja, by zaznaczyć różnicę w stosunku do niższych grup (Bourdieu 2005: 79). 
Napawanie się krajobrazem, kontemplowanie otoczenia odmiennego od widoków, do których przyzwyczaja miasto - a to przecież z ośrodkami miejskimi związane jest instytucjonalne funkcjonowanie antropologii - wydaje się czynnością tyleż oczywistą, co powszechną i poprzez stopień jej znormalizowania pozbawioną większego znaczenia. Warto jednak zadać pytanie, czy do przeżywania krajobrazu chłopi podchodzili podobnie jak etnografowie? Czy nie jest to przypadkiem czynność diametralnie odmienna ich codziennemu doświadczeniu?

W tych okolicznościach pojawiała się niekiedy pokusa związana z wykorzystaniem aury sprzyjającej do odpoczynku, która wpływała ujemnie na koncentrację i zdolność wykonywania zadań:

Poprzedniego dnia przechodziłam koło Huziorów idąc na górkę, żeby zobaczyć Tatry. (...) [Zagadnięta przez kobietę:] Wygląda młoda gaździna, staram się wyjaśnić, że dziś tylko oglądam widoki, ale ona patrzy na mnie podejrzliwie. Zapewne stąd dziś to wychodzenie naprzeciwko i wypytywanie, bo teraz wszyscy pokolei pytają mnie, gdzie wczoraj zaszłam i jak też wróciłam (EK: 17).

przy okazji [badań pasterstwa] wszystkie wolne chwile spędzałam w górach, ale nie starczyło już czasu na turystykę wysokogórską, o której marzyłam (Kopczyńska-Jaworska 2000: 52).

To [badania] jesienią robiłam, w październiku. Taka była złota jesień. $\mathrm{Z}$ resztą przepiękne mam wspomnienia z widoków po drodze. Przez lasy się szło, czy coś. Piękne te rude drzewa $(2011 / 011 / C)$.

Dawno nie miałam tak miłych badań. (...) Od kilku dni piękna pogoda, która utrudnia badania, ale jest bardzo ładnie (K III-91/154.b: 3).

Etnografowie w terenie podziwiają krajobraz, przyjemność sprawia im dobra, słoneczna pogoda, napawają się również „pięknymi widokami” - niezależnie, czy są to góry, las, jeziora lub morze. Świadectwa przenikania się perspektywy zawodowej i estetycznej jeszcze wydatniej ukazują liczne zdjęcia, które można znaleźć w spuściznach poszczególnych badaczy. Przykładowo wśród fotografii autorstwa Bożeny Stelmachowskiej o charakterze "analitycznym”, dokumentujących stan obejść i przejawy lokalnej kultury materialnej, można znaleźć wiele ujęć pejzaży (Wróblewski 2018: 138; P.III-23/132; P.III-23/177). Podobnie jak przywołane cytaty z zapisków i wypowiedzi także zdjęcia wskazują na towarzyszące pracy terenowej poszukiwanie i podziwianie piękna krajobrazu przez etnografów. Wrażenia estetyczne, zmysłowe doznania, związane z nimi emocje, a także wymiar intelektualny, wzajemnie się splatają, dając w efekcie wielowymiarowe doświadczenie terenowe, niezbędne w budowaniu wiedzy etnograficznej. Tym samym warto dowartościować pozaintelektualne aspekty pracy wykonywanej przez antropologów. Dopiero one pozwalają dostrzec i prześledzić trajektorię dyskursywnych uwarunkowań afektów, które wpływają na to, jak praktykowane są badania terenowe, a zatem jak realizowany jest ich wzór. Dzięki temu 
możliwe jest dostrzeżenie wagi niuansu związanego z etnograficzną optyką zawartą $\mathrm{w}$ przywoływanych fragmentach. Oto bowiem na ich podstawie można się przekonać, że za obiekt piękna i admiracji uznawano - przykładowo - osoby, przedmioty, okoliczności i zjawiska pogodowe, wreszcie - krajobraz, który intencjonalnie kategoryzowano zgodnie z przyswojonymi sobie kanonami estetycznymi. Z przedstawionych opinii etnografów nie można się dowiedzieć tylko jednego... Tego, czy sama wieś jest piękna. Prowadząc badania w obszarze wiejskim, Anna Kunachowicz wspomina wyłącznie o „pięknej pogodzie”; Kazimiera Zawistowicz-Adamska na dworze rześko oddycha mroźnym powietrzem; Anna Kowalska-Lewicka zachwyca się zarówno śniegiem skrzącym się w słońcu, jak i zgraną pracą chłopów i zwierząt pociągowych; Ewa Kamińska i Bronisława Kopczyńska-Jaworska - każda osobno - piękna poszukują poza wsią, spoglądając w stronę gór. Tym, co je zachwyca są niebo nad głową, górskie szczyty oglądane ze wzniesienia poza zabudowaniami, las mijany w trakcie badawczych wędrówek. Wieś jako taka nie stanowi dla nich przedmiotu admiracji, a przynajmniej literalnie nie pada ani jedno stwierdzenie, które by na to wskazywało.

Z obserwacji tej można wysunąć wniosek, że obowiązujące w etnografii estetyczne uwarunkowania recepcji rzeczywistości miały i prawdopodobnie mają nadal silnie jednostronne ukierunkowanie. Wieś jest ujmowana rozłącznie od otaczającego ją krajobrazu, sytuuje się $\mathrm{w}$ "martwym polu” widzenia, tak jakby badacze nie byli w stanie lub nie chcieli dostrzec związku tych przestrzeni. Być może ów dysjunktywny sposób konceptualizacji wynikał z pragmatycznych uwarunkowań, pozwalających całościowo ujmować krajobraz i przyrodę w kategoriach piękna, zaś w przypadku wsi tylko częściowo, względem wybranych aspektów jej funkcjonowania. Dzięki takiemu sposobowi zorganizowania dyskursu wieś dawało się łatwiej deprecjonować poprzez aplikowanie do jej opisu kategorii brudu.

Mam nadzieję, że przestanie padać deszcz. Zimno i mokro. Niby to pomaga bo ludzie siedzą $\mathrm{w}$ domu, ale sam badający ma kłopoty z przełamaniem niechęci do wyjścia z domu. Jeszcze do tego zmęczenie przywiezione z Krakowa i trzeba być bardzo dzielnym by więź społeczna była w tych warunkach wystarczająco silnym bodźcem (K III-91/154.a: 3-4).

Czuję się fatalnie. Jestem zaziębiona a zawsze wtedy nawala mi serce i w ogóle jestem do niczego. Na polu gẹsta wilgotna mgła i siappi coś pośredniego między rosą a deszczem. Drzewa zaczynają pokrywać się lodową osędzieliną (AKL: 17).

(...) nie było mowy o jakimkolwiek nagrywaniu. Gdybym miała magnetofon chociaż ten Grundig, który ważył 10 kilogramów się [nie?] nadawał do jakiś wojaży - wtedy nie było przecież żadnych dróg asfaltowych na Spiszu, były ścieżki, dróżki, błoto po kostki. Więc notowałam. (...) Na badania terenowe szło się bez względu na porę dnia, w nocy się wracało, $\underline{w}$ błocie, nie w błocie, bo przecież tych asfaltowych dróg było w sumie mało - tylko główne. Tak jak mówię, jak ktoś tego nie lubit, to cierpiał straszne mẹki. (...) Jest czarna noc, taka droga błotnista, kamienista, która idzie wzdłuż potoku przez las (2014/096/A). 


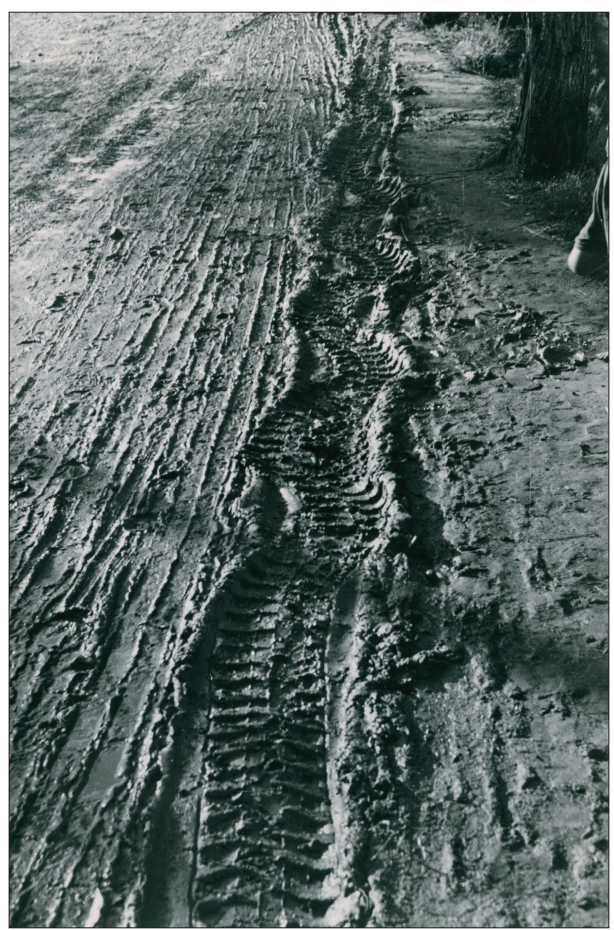

Fot. 4. Ślad samochodowy, Przeworsk, 1952

Koleina pozostawiona przez samochód terenowy etnografów. Obok widoczne odciski końskich kopyt i ślady po kołach wozów. Większość dróg wiejskich, placów i podwórzy w zagrodach była nieutwardzona, co utrudniało poruszanie się w niesprzyjających warunkach pogodowych. Błoto z rozmokłych dróg nie tylko lepiło się do butów, ale było też wnoszone do domostw. Bezkształtna masa, z którą etnografowie musieli się mierzyć, podróżując często na piechotę od wsi do wsi, symbolizuje nie tylko podejmowany przez nich wysiłek i cielesne cierpienie niedoli związanych z wykonywaną pracą, ale też zagrożenie dla ich zdyscyplinowania i efektywności.

Źródło: Fot. S. Deptuszewski (Muzeum Etnograficzne im. Seweryna Udzieli w Krakowie, Kolekcja ISPAN, nr inw. L/14.133)

Rewersem estetyzacji była tendencja do „poszukiwania egzotyki i dzikości” (Libera 1995a: 138). W tym względzie wskazania dotyczące brudu i smrodu miały podkreślać różnice cywilizacyjne i wysiłek związany z realizacją projektu modernizacji społecznej - piśmiennictwo etnograficzne, jeśli uwzględniało w opisie fizjologię i miazmatyczność chłopskiego ciała, pozwalało „zerwać ze wszystkim, co zwierzęce, przynajmniej w sferze publicznej" (Kuligowski 2012: 49) i umożliwiało samoidentyfikację piszących. Różnicę klasową określali zatem etnografowie zgodnie $\mathrm{z}$ warunkowanymi kulturowo standardami konstruowania nieczystości i wyobrażeniami o niej, wszak to „zapach wyznacza granice społeczne" (Kuligowski 2012: 50). Będąc "strażnik[ami] porządku i [własnej] higieny" (Kuligowski 2012: 49) w terenie, starali się, o ile było to możliwe, realizować ",normy osmologicznej neutralności” (Kuligowski 2012: 50). Zgodnie z tym często nieartykułowanym wprost przekonaniem - znajdującym za to wyraz 
w indywidualnych praktykach - Inny "sytuuje się w internum smrodu i brudu” (Kuligowski 2012: 57). Nieprzyjemny, lepki, mdlący i słodkawy zapach spoconego ciała, fermentujący zaduch bijący z chałup, od ludzi, zapach wysiłku i niemycia się - to jedna z tych wprawdzie niewidocznych, ale odczuwalnych, wręcz zmysłowo „namacalnych” i dojmujących barier, które można doświadczyć po dziś dzień, spotykając choćby osoby bezdomne. Taki mniej więcej musiał być też zapach wsi, co znajduje oddźwięk w kolejnym wspomnieniu z lat 70. minionego wieku:

Też miałam takie zderzenie cywilizacyjne niesamowite. To było fajne, ponieważ ci Szwedzi przyjechali własnym autobusem i spotkałam się z nimi w Krakowie, potem muszę wracać do tej Zubrzycy [na badania] a się okazało, że oni sobie jadą do Zakopanego. To stwierdzili, że pojadę z nimi do Zakopanego i w Nowym Targu mnie wysadzą - przesiądę się z Nowego Targu w autobus do Zubrzycy. Z Krakowa wyruszyłam autobusem - takim jak u nas w tej chwili się jeździ dalekobieżne, z klimatyzacją, pachnący... Wtedy to już był w ogóle luksusu niesamowity, że dywanik był w przejściu. Że w ogóle, prawda, to wszystko razem... I z tego takiego właśnie autobusu wysiadałam w Nowym Targu i wsiadałam do autobusu relacji [śmiech] Nowy Targ - Zubrzyca. Z tym całym tłumem ludzi niedomytych, gdzie ledwo mogłam stanąć, gdzie zastanawiałam się jak ja mam się chwycić w ogóle oparcia, bo to był jeszcze stary Jelcz - wszystko się lepiące brudem, z muchami. W odpowiednim, mm... Tak, że, bym powiedziała... - Ktoś mi teraz powiedział, że [mu] się marzy, czy w radio to nawet usłyszałam, że ktoś powiedział właśnie "taki mądry”, że: byłby świetny skansen, taki gdzie te zapachy dawnej wsi by były. Na przykład zapach gotowanej kapusty. Pomyślałam: „Człowieku! Co ty mówisz? Zapach dawnej wsi? To by chyba nikt tego nie wytrzymał!" No. To nawet w tej chwili nie ma gdzie się zetknąć z czymś takim. Tak sobie myślę, że tak wielokrotnie opowiadałam tę moją historię, tego zderzenia cywilizacyjnego, i w latach siedemdziesiątych, osiemdziesiątych, może jeszcze dziewięćdziesiątych, to robiło wrażenie. A w tej chwili, ponieważ ludzie kompletnie nie znają tych [minionych] realiów, jak wyglądało wnętrze autobusu relacji Nowy Targ - Zubrzyca, to po prostu, to jest w sumie rzecz nie do opowiedzenia. [Badacz:] Ten autobus żył po prostu własnym życiem.

Tak. Oj, tak! I tam tego życia było bardzo dużo [śmiech]. Na ludziach, wszędzie! (...) Także to takie przejście $\mathrm{z}$ tego jednego świata w ten drugi i kawałek tego świata, można powiedzieć, przyjechał tym autobusem - tego innego świata. Czystego przede wszystkim, świata pachnącego w ten taki, no... no... pff... Potwornie, potwornie, to brudne było wszystko (2017/116/D).

Brud niezależnie od tego, jaką postać przybierze, „nie jest jakością samą w sobie, lecz odnosi się wyłącznie do tego, co ma związek z granica, zwłaszcza zaś przedstawia przedmiot upadły z tej granicy, drugą jej stronę, margines" (Kristeva 2007: 68). Owa kleista, przywierająca do palców bezkształtna, trudna do zidentyfikowania i nazwania - nawet po latach - obrzydliwość przyprawia o dreszcze. Zarazem w sposób najbardziej dojmujący wyznacza granicę między przedstawicielami różnych światów: miasta i wsi, etnografami a chłopami. Inny, choćby mówił tym samym lub podobnym językiem, chociaż byłby tego samego 
koloru skóry, tej samej narodowości, pozostanie poza obszarem, który badacz może „nazwać swoim” (Kristeva 2007: 15); istnieje po to, by się z nim nie identyfikować, by mu się przeciwstawić - jego istocie, formie życia, jakie prowadzi, tak bardzo obcej codzienności i przyzwyczajeniu badaczy. Inny - jak przekonuje Kristeva - "zamieszkując mnie jako alter ego (...) za pomocą odrazy” (Kristeva 2007: 15), swoją obecnością wskazuje granice tej „własnej” przestrzeni badacza wyznaczanej $w$ tak wielkim trudzie i znoju. To właśnie z nim przybysz musi się konfrontować, by poprzez ambiwalencję reakcji ostatecznie nadać kształt i ramy własnej podmiotowości.

Istotnie, teren jest momentem próby. Inny musi zaś zajmować uprzednio wyznaczone, marginalne miejsce, by nie rozpadł się „podmiotowy” profil kultury profesjonalnej antropologa i jego z nią identyfikacja. Tu właśnie z całą mocą uwidacznia się istota tkwiąca w modelu praktykowania badań terenowych przyjęta $\mathrm{w}$ antropologii. Ona to zdecydowała zarazem o stagnacji dyskursu etnograficznego w Polsce, który na długie dekady zakrzepł w "ludoznawczej zmianofobii” czy wręcz „histerii zmiany” (Węglarz 1994: 95; Burszta 2014: 107-110), pozwalając unikać konfrontacji z rzeczywistością wsi odbiegającą od oczekiwań. Postponowana przez Jamesa Clifforda „praktyka intensywnego zamieszkania” czy też „intensywne przebywanie” (Clifford 2004: 142) - ów osobliwy „fetysz badania opartego na sytuacji face to face" (Majbroda 2012: 358) - mimo obiekcji krytyków wpływa na sposób bezpośredniego doświadczania rzeczywistości i stopień zanurzenia w świecie Innego. Tym samym długotrwałe badania terenowe, prowadzone $\mathrm{w}$ przestrzennym i psychicznym oddzieleniu od rodzimej kultury antropologa, wymuszające na nim zmianę przyzwyczajeń, fizycznie dotkliwe, uruchamiające ciało i różne jego - być może dotąd nierozpoznane - rejestry, winno się traktować nie jako metaforę, ale jako swoiste dla wskazanej dyscypliny doświadczenie formacyjne, zespolone z tą praktyką. Konieczność mierzenia się z różnicą w sobie - różnicą uświadomioną i poddaną refleksji - uruchamia to, co można nazwać etnografią zmieniającą (ewentualnie: transformującą). Wstrząsający ciałem dreszcz obrzydzenia to epifania otwierająca drogę przemiany i zrozumienia dzięki napięciu między awersją, afektem a przyjemnością:

Odczuwam wstręt tylko wtedy, gdy Inny umościł się na miejscu i w punkcie tego, co będzie „mną". To nie inny, z którym się utożsamiam ani którego wchłaniam, lecz Inny, który mnie poprzedza i bierze mnie w posiadanie, a poprzez to posiadanie sprawia, że jestem. Posiadanie wcześniejsze niż moje pojawienie się (...). Nieodłączne wpisanie znaczeniowości [signifiance] w ciało człowieka" (Kristeva 2007: 15-16).

Praktyka etnograficzna ma jeszcze jedną postać. To badania o zmniejszonej intensywności, polegające na tymczasowym lub ograniczonym zawieszaniu kontaktów z dotychczasowym otoczeniem czy doraźnej rezygnacji z codziennego trybu życia, do którego przywykł antropolog. Granica nie jest zatem wyraźna i nie wydaje się absolutna, jej przekroczenie nie wymaga szczególnego poświęcenia, zaś z samego terenu łatwo jest się wycofać. Badania mogą mieć również 
charakter wędrowniczy, nie dając tym samym stałego zakorzenienia wśród określonej społeczności, lub też trwają na tyle krótko, że nie naruszają rytmu życia i nawyków antropologa. Badania takie można nazwać etnografią wizytacyjną. Jej istotą nie jest przemiana. (By ta mogła się dokonać, niezbędne jest zerwanie). Ma ona raczej charakter konserwujący. $Z$ jednej strony pozwala na rozbudowę wiedzy i gromadzenie informacji, zaś z drugiej, umożliwia utrzymanie stabilności dyskursu antropologicznego w niezmienionej postaci poprzez ujarzmianie jego funkcjonariuszy. W tym kontekście zetknięcie $\mathrm{z}$ brudem prowadzi nie tyle do przekształcenia działającego podmiotu, ile utwierdzenia jego kompozycji, zachowania i konserwacji dotychczasowego habitusu. Tak kontekstualizowany kontakt nie ma na celu uruchamiania ciała. Jeżeli już do tego dochodzi, to jedynie w sposób skonwencjonalizowany, to jest taki, który realizował się jako zestaw aprobowanych i rozpoznanych $\mathrm{w}$ ramach kultury profesjonalnej zestandaryzowanych wzorów doświadczania i zmysłowego postrzegania rzeczywistości. Idea brudu wyraża bowiem system symboliczny (Douglas 2007: 76), a ten w przypadku antropologii opiera się na negacji podobieństwa do "przedmiotu" badań, a w konsekwencji służy - co paradoksalne - podważeniu związku z Innym. Nie dziwi zatem tożsamościowe, na wskroś supremacyjne przekonanie pojawiające się w wypowiedziach polskich etnografów, iż byli

instruowani i przekazywało się to innym grupom studenckim w czasie obozów [Międzyuczelnianych Obozów Etnograficznych/praktyk terenowych], żeby się nie fraternizować ze wsią. (...) To był taki, no, pewien dystans utrzymany. (...) Myśmy po prostu byli jak gdyby z innego gatunku, z innej planety (2011/011/A).

Brud, i jego pojawienie się w polu uwagi, to „produkt uboczny systematycznego porządkowania i klasyfikacji rzeczy, o tyle, o ile porządkowanie wymaga odrzucenia nieprzystających elementów" (Douglas 2007: 77).

Sięgając po przykład typowej praktyki badawczej realizowanej przez polskich etnografów, można wskazać znaczenie brudu jako wyróżnika nie tylko odrębności, ale także zmysłowo oddziałującego markera systemu wyobrażeń, znaczeń i wartościowań warunkowanych dyskursem antropologicznym. Dopiero taka perspektywa ukaże z mocą specyficzne dla danej kultury „rodzaje ryzyka i problemy" (Douglas 2007: 156), które z kolei stanowią konstytutywną składową struktury dyskursu pozwalającą lepiej mobilizować i reorganizować układ sił oraz ciał podporządkowanych. By zobrazować skuteczność i dynamikę ruchu od-do, wystarczy przywołać wspomnienia osób, które choćby uczestniczyły w badaniach penetracyjnych, objazdach i obozach naukowych organizowanych przez Romana Reinfussa w ramach sukcesywnie prowadzonych badań dokumentujących plastykę ludową (Fryś-Pietraszkowa 1980). W lapidarnym - ale jakże gęstym - wspomnieniu jednego z takich wyjazdów zarysowuje się niejednoznaczność brudu, który może jednocześnie skalać, zachwycać, fascynować i odpychać: 
to była moja pierwsza wyprawa [z Reinfussem], byłem wtedy na czwartym czy piątym roku - trafiłem i widziałem kurną chatę zamieszkaną przez dwóch starych kawalerów. Przeżycie nieprawdopodobne jak wygląda kurna chata. Kurna chata, która jest od podłogi aż po dach z sadzą. Jak zaświeciło słońce, to się świeciło. Od tej sadzy się odbijało jak od lustra. Mieszkało dwóch starych kawalerów, którzy mieli kuchnię, na tej kuchni rozkładali ognisko i to się dymiło. Więc prawdziwą kurną chatę widziałem - byłem w środku! Rozmawiałem chodząc bardzo ostrożnie, żeby się nie dotknạć ściany (2011/024/A).

Podczas badań terenowych zmysłowo doświadczany kontakt z brudem czy też jego namacalna obecność, z którą należy się zmierzyć, okazuje się bodźcem uruchamiającym klasowo warunkowany habitus. To, co zakłóca porządek czystości - diametralnie odbiegając od reżimu higienicznego, do jakiego przywykli etnografowie - nie tylko zagraża temu porządkowi, ale też stanowi źródło lęku przed zetknięciem, przed skalaniem. Wszak „,człowiek dopuszczający się nieczystości jako obiekt potępienia jest podwójnie wstrętny: po pierwsze dlatego że przekroczył granicę, po wtóre dlatego że zagroził otoczeniu" (Douglas 2007: 171). By do niego nie doszło, badacz musi rozmyślnie posługiwać się swoim ciałem, stale uważając na własne ruchy i działania. Kontakt i konfrontacja z brudem, choć obarczone ryzykiem zarazem symbolicznym i fizycznym, jest przede wszystkim mieszanką sprzeczności - odrazy i fascynacji, pięknego i strasznego zarazem.

Opisane natknięcie się na kurną chatę można wpisać w ramy doświadczenia egzystencjalnego, które jest emanacją tego, co istotnie pierwotne, dzikie. To budzące emocje wyzwanie rzucone przyzwyczajeniu, które zostaje jednak uśmierzone i włączone w obręb dyskursu antropologicznego. Ostatecznie bowiem nie została zakwestionowana sama granica - choć dochodzi do spotkania przedstawicieli i artefaktów z dwóch odmiennych klasowo światów, to jednak nie ma mowy o fizycznym, namacalnym zetknięciu się. Ma ono co najwyżej wymiar intelektualny i wyobrażony, jest poddaną estetyzacji realizacją awanturniczego fantazmatu odkrywcy, który wyrusza w świat w celu doświadczania przygód. Wszak we wspomnieniach etnografów właśnie taką rolę pełnią wielokrotnie powtarzane napomknięcia o heroizmie, jakiego wymagało od nich mierzenie się z tą śmierdzącą, „"przyprawiającą o straszne męki” rzeczywistością wsi. Dzieje się tak, ponieważ ludzkie „zachowania związane z nieczystością wyrażają reakcję odrzucenia wszystkich przedmiotów lub myśli mogących zakłócić lub naruszyć klasyfikacje, do których jesteśmy przywiązani" (Douglas 2007: 77). W ostatecznym rachunku nie o doświadczenie obcych kulturowo realiów tu chodzi, lecz o odtwarzanie i ugruntowywanie ram reprezentowanej obecnością przybysza kultury profesjonalnej, która by działała i była skuteczną, wymaga odpowiedniej scenografii. Spleciona $\mathrm{z}$ nią „idea brudu przenosi nas wprost $\mathrm{w}$ sferę symboli i wskazuje na powiązanie z systemami czystości, których symboliczny charakter jest jeszcze bardziej oczywisty" (Douglas 2007: 77).

Zetknięcie z brudem, konieczność radzenia sobie z jego obecnością, dyskomfort, starania o utrzymanie czystości - to warunek zachowania poczucia różnicy wobec Innego. Dzięki niemu dokonuje się rozpoznanie własnej tożsamości 
i pełniejsza identyfikacja z reprezentowanym przez siebie środowiskiem zawodowym. Motywowane względami higienicznymi i estetycznymi poczucie odrębności stanowi klucz do zrozumienia sposobów wartościowania i oceniania Innego przez etnografów. W świecie Innego, w świecie tego, co wzgardzone, zwymiotowane, odstręczające, "gdzie Inny się stoczył", niezbędny jest "wysiłek estetyczny", który "polega na ponownym wyznaczeniu kruchych granic bytu mówiącego", w doświadczeniu czego "»podmiot « i "przedmiot« odpychają się, konfrontują się ze sobą, upadają i zaczynają od nowa" (Kristeva 2007: 22). Chłop nigdy nie mógł być tym samym co "pan”; tak samo "dziki" nigdy nie będzie taki jak antropolog. Dla istnienia dyskursu liczy się tylko różnica. Jej operatorami są Inny i klasowo warunkowana dystynkcja. Brud zapobiega rozpoznaniu siebie w Innym.

\section{Zakończenie}

Kategoria brudu jako część kultury profesjonalnej etnologów - choć nie jest problematyzowana przez badaczy - okazuje się jedną z ważniejszych dla zrozumienia funkcjonowania i sposobu wewnętrznego uorganizowania dyskursu antropologicznego. Jej znaczenie ujawnia się przede wszystkim w praktyce badawczej poprzez zindywidualizowane reakcje na powodowane brudem bodźce zmysłowe, a także pod postacią ucieleśnionych wzorów zachowań nabywanych $\mathrm{w}$ trakcie treningu zawodowego, których uruchomienie ta obecność powoduje.

Antropologia jest jedną z wielu dziedzin wiedzy powołanych do istnienia w XIX wieku. W epoce kolejnych odkryć geograficznych, a także zmian społecznych postępujących wraz z industrializacją i kolonializmem, nauka ta miała dostarczać informacji na temat Innego. W kontekście polskim na postrzeganiu wsi i warstwy chłopskiej zaważyła „ideologia ludoznawcza”. Jej przedłużeniem na gruncie etnografii był proces estetyzacji wsi rozpięty między afektywnymi kategoriami zachwytu bądź wstrętu. Odnoszenie się do kategorii brudu w konceptualizacjach czynionych przez etnografów pozwalało im na jednostronne podtrzymywanie różnicy i poczucia odrębności wobec chłopów. By supremacja dyscypliny była możliwa, Inny antropologii musiał pozostać w granicy umorusanego, ubłoconego, śmierdzącego i przy prawiającego o mdłości, naznaczonego brudem świata. A przynajmniej tak był postrzegany przez badaczy, często nieświadomych co do mechanizmu działania kierującej nimi klasistowskiej optyki warunkowanej dyskursem.

\section{Literatura}

\section{Publikacje}

Anderson, B.G. (1990). First Fieldwork. The Misadventures of an Anthropologist. Prospect Heights: Waveland Press.

Arens, W. (2010). Mit ludożercy. Antropologia i antropofagia. Przeł. W. Pessel. Warszawa: Wydawnictwa Uniwersytetu Warszawskiego. 
Ashenburg, K. (2009). Historia brudu. Przeł. A. Górska. Warszawa: Bellona.

Barley, N. (1997). Niewinny antropolog. Notatki z glinianej chatki. Przeł. E.T. Szyler. Warszawa: Prószyński i S-ka.

Barley, N. (1998). Plaga gąsienic. Powrót do afrykańskiego buszu. Przeł. E.T. Szyler. Warszawa: Prószyński i S-ka.

Barley, N. (2000). Bezpieczny sport. Przeł. E.T. Szyler. Warszawa: Prószyński i S-ka.

Barth, F. (2007). Wielka Brytania i kraje Commonwealthu. W: F. Barth, A. Gingrich, R. Parkin, S. Silverman, Antropologia. Jedna dyscyplina, cztery tradycje: brytyjska, niemiecka, francuska i amerykańska (s. 11-72). Przeł. J. Tegnerowicz. Kraków: Wydawnictwo Uniwersytetu Jagiellońskiego.

Bataille, G. (2007). Erotyzm. Przeł. M. Ochab. Gdańsk: słowo/obraz terytoria.

Bataille, G. (2008). Historia erotyzmu. Przeł. I. Kania. Warszawa: Wydawnictwo Aletheia.

Bataille, G. (2009). Łzy Erosa. Przeł. T. Swoboda. Gdańsk: słowo/obraz terytoria.

Bateson, G., Mead, M. (1942). Balinese Character. A Photographic Analysis. New York: The New York Academy of Sciences.

Benedict, B. (1983). The Anthropology of World's Fairs. San Francisco's Panama Pacific International Exposition of 1915. London: The Lowie Museum of Anthropology.

Benedyktowicz, Z. (2000). Portrety „obcego". Od stereotypu do symbolu. Kraków: Wydawnictwo Uniwersytetu Jagiellońskiego.

Benedyktowicz, Z., Czaja, D. (2014). Nasze Macondo. Dariusz Czaja rozmawia ze Zbigniewem Benedyktowiczem. Tygodnik Powszechny, 8, 23 lutego 2014, dodatek specjalny: Wariacje Kolbergowskie, 6-8.

Blacking, J. (ed.) (1977). The Anthropology of the Body. London - New York: Academic Press.

Blanchard, P., Bancel, N., Boëtsch, G., Deroo, E., Lemaire, S., Forsdick, C. (eds.). (2008). Human Zoos. Science and Spectacle in the Age of Colonial Empires. Transl. T. Bridgeman. Liverpool: Liverpool University Press.

Blanchard, P., Boëtsch, G., Snoep, N.J. (2011). Human Zoos. The Invention of the Savage. Arles Paris: Musée du Quai Branly.

Bourdieu, P. (2005). Dystynkcja. Społeczna krytyka władzy sądzenia. Przeł. P. Biłos. Warszawa: Wydawnictwo Naukowe Scholar.

Brocki, M. (2011). Sposoby artykulacji potocznych doświadczeń a porządek doświadczenia wymuszony praktyką etnograficzną. W: T. Rakowski, A. Malewska-Szałygin (red.), Humanistyka i dominacja. Oddolne doświadczenia społeczne w perspektywie zewnętrznych rozpoznań (s. 47-58). Warszawa: Instytut Etnologii i Antropologii Kulturowej Uniwersytetu Warszawskiego.

Brocki, M., Górny, K., Kuligowski, W. (red.). (2006). Kultura profesjonalna etnologów w Polsce. Wrocław: Katedra Etnologii i Antropologii Kulturowej Uniwersytetu Wrocławskiego.

Brownell, S. (ed.) (2008). The 1904 Anthropology Days and Olympic Games. Sport, Race, and American Imperialism. Lincoln - London: University of Nebraska Press.

Burke, P. (2009). Kultura ludowa we wczesnonowożytnej Europie. Przeł. R. Pucek, M. Szczubiałka. Warszawa: Wydawnictwa Uniwersytetu Warszawskiego.

Burke, P. (2016). Spoteczna historia wiedzy. Przeł. A. Kunicka. Warszawa: Fundacja Aletheia.

Burszta, W. (2014). Etnografia ludowości. W: B. Fatyga, R. Michalski (red.), Kultura ludowa. Teorie, praktyki, polityki (s. 107-132). Warszawa: Instytut Stosowanych Nauk Społecznych.

Caillois, R. (2009). Człowiek i sacrum. Przeł. A. Tatarkiewicz, E. Burska. Warszawa: Oficyna Wydawnicza Volumen.

Cassell, J. (ed.) (1987). Children in the Field. Anthropological Experiences. Philadelphia: Temple University Press. 
Cesara, M. (1982). Reflections of a Woman Anthropologist. No Hiding Place. London - New York: Academic Press.

Chéroux, C. (2014). Wernakularne. Eseje z historii fotografii. Przeł. T. Swoboda. Warszawa: Fundacja Archeologia Fotografii.

Classen, C. (1993). Worlds of Sense. Exploring the Senses in History and across Cultures. London - New York: Routledge.

Classen, C. (1997). Foundations for an Anthropology of the Senses. International Social Science Journal, 153, 401-412.

Classen, C., Howes, D., Synnott, A. (1994). Aroma. The Cultural History of Smell. London New York: Routledge.

Clifford, J. (2000). Ktopoty z kultura. Dwudziestowieczna etnografia, literatura i sztuka. Przeł. E. Dżurak, J. Iracka, E. Klekot, M. Krupa, S. Sikora, M. Sznajderman. Warszawa: Wydawnictwo KR.

Clifford, J. (2004). Praktyki przestrzenne: badania terenowe, podróże i praktyki dyscyplinujące w antropologii. Przeł. S. Sikora. W: M. Kempny, E. Nowicka (red.), Badanie kultury. Elementy teorii antropologicznej. Kontynuacje (s. 139-179). Warszawa: Wydawnictwo Naukowe PWN.

Coetzee, J.M. (2009). Białe pisarstwo. O literackiej kulturze Afryki Południowej. Przeł. D. Żukowski. Kraków: Wydawnictwo Znak.

Conklin, A.L. (2013). In the Museum of Man. Race, Anthropology, and Empire in France, 18501950. Ithaca - New York: Cornell University Press.

Coombes, A.E. (1994). Reinventing Africa. Museums, Material Culture and Popular Imagination in Late Victorian and Edwardian England. New Haven - London: Yale University Press.

Crary, J. (2009). Zawieszenia percepcji. Uwaga, spektakl i kultura nowoczesna. Przeł. Ł. Zaręba, I. Kurz. Warszawa: Wydawnictwa Uniwersytetu Warszawskiego.

Csordas, T.J. (1990). Embodiment as a Paradigm for Anthropology. Ethos, 18 (1), 5-47.

Csordas, T.J. (1993). Somatic Modes of Attention. Cultural Anthropology, 2 (8), 135-156.

Csordas, T.J. (2002). Body/Meaning/Healing. Basingstoke: Palgrave Macmillan.

Csordas, T.J. (ed.) (1994). Embodiment and Experience. The Existential Ground of Culture and Self. Cambridge - New York: Cambridge University Press.

Czaja, D. (2000). Malinowski o kolorach. Między estetyką a antropologią. Konteksty, 1, 385-397.

Czapiga, M., Konarska, K. (red.). (2017). Strach, wstręt, wstyd i inne fobie. Wrocław: Wydawnictwo Uniwersytetu Wrocławskiego.

Czyżewski, A. (2001). Trzewia Lewiatana. Antropologiczna interpretacja utopii miasta-ogrodu. Kraków: Wydawnictwo Uniwersytetu Jagiellońskiego.

Davies, J., Spencer, D. (eds.) (2010). Emotions in The Field. The Psychology and Anthropology of Fieldwork Experience. Stanford: Stanford University Press.

DeVita, P.R. (ed.) (1990). The Humbled Anthropologist. Tales from the Pacific. Belmont: Wadsworth Publishing Company.

DeVita, P.R. (ed.) (1992). The Naked Anthropologist. Tales from around the World. Belmont: Wadsworth Publishing Company.

Douglas, M. (2007). Czystość i zmaza. Przeł. M. Bucholc. Warszawa: Państwowy Instytut Wydawniczy.

Drzał-Sierocka, A., Kowalewska, M. (red.). (2016). A fe! Społeczno-kulturowe konteksty wstrętu i obrzydliwości. Gdańsk: Wydawnictwo Naukowe Katedra.

Dumont, J.-P. (1978). The Headman and I. Ambiguity and Ambivalence in the Fieldworking Experience. Austin: University of Texas Press. 
Edwards, E. (2001). Raw Histories. Photographs, Anthropology and Museums. Oxford - New York: Berg.

Firth, R. (1989). Second Introduction 1988. In: B. Malinowski, A Diary in the Strict Sense of the Term (p. XXI-XXXI). London: The Athlone Press.

Flinn, J., Marshall, L., Armstrong, J. (eds.). (1998). Fieldwork and Families. Constructing New Models for Ethnographic Research. Honolulu: University of Hawai'i Press.

Foucault, M. (1987). Historia szaleństwa w dobie klasycyzmu. Przeł. H. Kęszycka. Warszawa: Państwowy Instytut Wydawniczy.

Foucault, M. (1998). Nadzorować i karać. Narodziny więzienia. Przeł. T. Komendant. Warszawa: Fundacja Aletheia.

Foucault, M. (2013). Kim pan jest, profesorze Foucault? Debaty rozmowy, polemiki. Przeł. K.M. Jaksender, Kraków: Esprons-Ostrogi.

Fowler, D.D., Hardesty, D.L. (eds.). (1994). Others Knowing Others. Perspectives on Ethnographic Careers. Washington: Smithsonian Institution Press.

Frykman, J., Löfgren, O. (2007). Narodziny człowieka kulturalnego. Kształtowanie się klasy średniej w Szwecji XIX i XX wieku. Przeł. G. Sokół. Kęty: Wydawnictwo Marek Derewiecki.

Fryś-Pietraszkowa, E. (1980). Archiwum dokumentacji Polskiej Sztuki Ludowej Instytutu Sztuki PAN. Polska Sztuka Ludowa, 3-4, 137-142.

Gaudio, M. (2008). Engraving the Savage. The New World and Techniques of Civilization. Minneapolis - London: University of Minnesota Press.

Geertz, C. (2000). Dzieło i życie. Antropolog jako autor. Przeł. E. Dżurak, S. Sikora. Warszawa: Wydawnictwo KR.

Gellner, E. (1991). Narody i nacjonalizm. Przeł. T. Hołówka. Warszawa: Państwowy Instytut Wydawniczy.

Gold, P. (ed.) (1986). Women in the Field. Anthropological Experiences. Berkeley: University of California Press.

Goody, J. (2002). The Anthropology of the Senses and Sensations. La Ricerca Folklorica, 45, 17-28.

Greenhalgh, P. (1988). Ephemeral Vistas. The Expositions Universelles, Great Exhibitions and World's Fairs, 1851-1939. Manchester: Manchester University Press.

Grochowski, P. (2009). Dziady. Rzecz o wędrownych żebrakach i ich pieśniach. Torun: Wydawnictwo Naukowe Uniwersytetu Mikołaja Kopernika.

Halstead, N., Hirsch, E., Okely, J. (eds.) (2008). Knowing How to Know. Fieldwork and the Ethnographic Present. New York: Berghahn Books.

Hastrup, K. (2008). Droga do antropologii. Między doświadczeniem a teorią. Przeł. E. Klekot. Kraków: Wydawnictwo Uniwersytetu Jagiellońskiego.

Hendry, J. (1999). An Anthropologist in Japan. Glimpses of Life in the Field. New York: Routledge.

Hinsley, C.M., Wilcox D.R. (eds.) (2016). Coming of Age in Chicago. The 1893 World's Fair and the Coalescence of American Anthropology. Lincoln: University of Nebraska Press.

Hoffenberg, P.H. (2001). An Empire on Display. English, Indian, and Australian Exhibitions from the Crystal Palace to the Great War. Berkeley - Los Angeles - London: University of California Press.

Hobbs, D., Wright, R. (eds.) (2006). The SAGE Handbook of Fieldwork. London: SAGE.

Howes, D. (2003). Sensual Relations. Engaging the Senses in Culture and Social Theory. Ann Arbor: University of Michigan Press.

Howes, D. (2010a). Response to Sarah Pink. Social Anthropology, 3 (18), 333-336.

Howes, D. (2010b). Response to Sarah Pink. Social Anthropology, 3 (18), 338-340.

Howes, D. (ed.) (1991). The Varieties of Sensory Experience. A Sourcebook in the Anthropology of the Senses. Toronto - London: University of Toronto Press. 
Howes, D. (ed.) (2005). Empire of the Senses. The Sensual Culture Reader. Oxford: Berg. Hugo, W. (1962). Nędznicy. T. IV. Przeł. K. Byczewska. Warszawa: Państwowy Instytut Wydawniczy.

Jackson, A. (ed.) (1987). Anthropology at Home. London - New York: Tavistock Publications. Jackson, M. (1983a). Knowledge of the Body. Man, 18, 327-345.

Jackson, M. (1983b). Thinking through the Body. An Essay on Understanding Metaphor. Social Analysis, 14, 127-148.

Jasiewicz, Z. (2011). Początki polskiej etnologii i antropologii kulturowej (od końca XVIII wieku do roku 1918). Poznań: Instytut im. Oskara Kolberga.

Kafar, M., Kamińska-Jatczak, I. (2017). W kręgu transgeneracyjnych biografii naukowych. Zaczynając od Heleny Radlińskiej i Kazimiery Zawistowicz-Adamskiej. Nauki o Wychowaniu. Studia Interdyscyplinarne, 1 (4), 171-193.

Kamiński, A. (1967). Współpraca Kazimiery Zawistowicz-Adamskiej z Heleną Radlińską. Łódzkie Studia Etnograficzne, 9, 109-115.

Kaniowska, K. (2011). Społeczność wiejska czytana dzisiaj. Łódzkie Studia Etnograficzne, 50, 117-130.

Kaniowska, K. (2013). Projekt antropologii wrażliwej. Doświadczenie, narracja i zaangażowanie w „Społeczności wiejskiej” K. Zawistowicz-Adamskiej. W: D. Kasprzyk (red.), Nie tylko o wsi... Szkice humanistyczne dedykowane profesor Marii Wieruszewskiej-Adamczyk (s. 227-239). Łódź: Wydawnictwo Uniwersytetu Łódzkiego.

Kaniowska, K. (2014). Narracja i zaangażowanie. Kazimiera Zawistowicz-Adamska i Spoteczność wiejska. W: G. Kubica, K. Majbroda (red.), Obserwatorki z wyobraźnią. Etnograficzne i socjologiczne pisarstwo kobiet (s. 229-240). Wrocław: Polskie Towarzystwo Ludoznawcze, Uniwersytet Wrocławski.

Konarska, K. (red.) (2011). Ciało cielesne. Wrocław: Wydawnictwo Uniwersytetu Wrocławskiego. Kopczyńska-Jaworska, B. (2000). W górach i w mieście. W: Moja droga do nauki (s. 37-63). Łódź: Łódzkie Towarzystwo Naukowe.

Kordjak, J. (red.) (2016). Polska - kraj folkloru? Warszawa: Zachęta - Narodowa Galeria Sztuki.

Korduba, P. (2013). Ludowość na sprzedaż. Towarzystwo Popieranie Przemystu Ludowego, Cepelia, Instytut Wzornictwa Przemysłowego. Warszawa: Fundacja Bęc Zmiana, Narodowe Centrum Kultury.

Kowalska-Lewicka, A. (1958). Badania etnograficzne na Podhalu. Etnografia Polska, 1, 240-256.

Kowalski, P. (red.) (2009). Tabu, etykieta, dobre obyczaje. Wrocław: Wydawnictwo Uniwersytetu Wrocławskiego.

Kristeva, J. (2007). Potęga obrzydzenia. Esej o wstręcie. Przeł. M. Falski. Kraków: Wydawnictwo Uniwersytetu Jagiellońskiego.

Kubica, G. (2008). Wstęp. W: B. Malinowski, Dziennik w ścistym znaczeniu tego wyrazu (s. 5-36). Kraków: Wydawnictwo Literackie.

Kubica, G. (2018). Kobiety i (nie)obecność problematyki płci i gender w polskim ludoznawstwie i antropologii społeczno-kulturowej. Szkic historyczno-autoetnograficzny. Lud, 102, 155-184.

Kulick, D., Willson, M. (eds.) (1995). Taboo. Sex, Identity, and Erotic Subjectivity in Anthropological Fieldwork. London - New York: Routledge.

Kuligowski, W. (2012). Brud, smród i etniczność. Aromafobie dawnej Rzeczypospolitej. W: M. Sztandara (red.), Brud. Idee - dylematy - sprawy (s. 47-58). Opole: Wydawnictwo Uniwersytetu Opolskiego. 
Kulikowska, K., Obracht-Prondzyński, C. (red.). (2015). Śmieć w kulturze. Gdańsk: Wydawnictwo Naukowe Katedra.

Kuper, A. (2009). Wymyślanie społeczeństwa pierwotnego. Transformacje mitu. Przeł. T. Sieczkowski, A. Dąbrowska. Kraków: Wydawnictwo Uniwersytetu Jagiellońskiego.

Laporte, D. (2000). History of Shit. Transl. N. Benabid, R. el-Khoury. Cambridge - London: The MIT Press.

Le Corbusier (2012). Wstronęarchitektury. Przeł. T. Swoboda. Warszawa: Centrum Architektury.

Lévi-Strauss, C. (2008). Smutek tropików. Przeł. A. Steinsberg. Warszawa: Wydawnictwo Aletheia.

Lewin, E., Leap, W.L. (eds.) (1996). Out in the Field. Reflections of Lesbian and Gay Anthropologists. Urbana - Chicago: University of Illinois Press.

Libera, Z. (1995a). Lud ludoznawców. Kilka rysów do opisania fizjognomii i postaci ludu naszego czyli etnograficzna wycieczka po XIX wieku. W: A. Posern-Zieliński (red.), Etnologia polska między ludoznawstwem a antropologia (s. 137-152). Poznań: Wydawnictwo Drawa.

Libera, Z. (1995b). Rzyć, aby żyć. Rzecz antropologiczna w trzech aktach z prologiem i epilogiem. Tarnów: Liber Novum.

Libera, Z. (1996). Wstęp do nosologii napisany z wyczuciem antropologicznym przez Zbigniewa Liberę doktora nauk humanistycznych w zakresie historii ze specjalnościa - etnografia. Wrocław: Wirydarz.

Libera, Z. (1997). Mikrokosmos, makrokosmos i antropologia ciała. Tarnów: Liber Novum.

Libera, Z. (2003). Znachor w tradycjach ludowych i popularnych XIX-XX wieku. Wrocław: Towarzystwo Przyjaciół Ossolineum.

Lindfors, B. (ed.). (1999). Africans on Stage. Studies in Ethnological Show Business. Bloomington - Indianapolis: Indiana University Press.

Lubaś, M. (2014). Writing Culture i spór o kształt krytyki wiedzy. Zeszyty Etnologii Wrocławskiej, 2 (21), 39-65.

Lyndon, J. (2005). Eye Contact. Photographing Indigenous Australians. Durham - London: Duke University Press.

Maanen, J. van (1988). Tales of the Field. On Writing Ethnography. Chicago: University of Chicago Press.

Maines, R.P. (2011). Technologia orgazmu. "Histeria”, wibrator i zaspokojenie seksualne kobiet. Przeł. M. Madej. Warszawa: Wydawnictwo Aletheia.

Majbroda, K. (2012). Fieldwork jako fakt (nie tylko) terenowy. Rocznik Antropologii Historii, 1 (2), 349-358.

Majbroda, K. (2013). Drogi wiedzy w antropologii społeczno-kulturowej po zwrocie ku sensoryczności i niedyskursywnemu doświadczaniu rzeczywistości. Lud, 97, 17-38.

Majbroda, K. (2014). O kontekstach i stylach recepcji książki Writing Culture. The Poetics and Politics of Ethnography w polskiej antropologii społeczno-kulturowej. Zeszyty Etnologii Wrocławskiej, 2 (21), 11-28.

Majewski, T. (red.) (2009). Rekonfiguracje modernizmu. Nowoczesność i kultura popularna. Warszawa: Wydawnictwa Akademickie i Profesjonalne.

Malinowski, B. (1967). A Diary in the Strict Sense of the Term. New York: Harcourt, Brace \& World.

Malinowski, B. (2008). Dziennik w ścisłym tego słowa znaczeniu. Kraków: Wydawnictwo Literackie.

Marcus, G., Clifford, J. (eds.) (1984). Writing Culture. The Poetics and Politics of Ethnography. Berkeley - Los Angeles - London: University of California Press. 
Marcus, S. (1985). The Other Victorians. A Study of Sexuality and Pornography in Mid-Nineteenth-Century England. New York: W.W. Norton.

Markowitz, F., Ashkenazi, M. (eds.) (1999). Sex, Sexuality, and the Anthropologist. Urbana: University of Illinois Press.

Mauss, M. (2001). Socjologia i antropologia. Przeł. M. Król, K. Pomian, P. Szacki. Warszawa: Wydawnictwo KR.

Maxwell, A. (1999). Colonial Photography and Exhibitions. Pepresentations of the 'Native' and the Making of European Identities. London - New York: Leicester University Press.

McLean, A., Leibing, A. (eds.) (2007). The Shadow Side of Fieldwork. Exploring the Blurred Borders between Ethnography and Life. Malden: Blackwell Publishing.

Michajłowa, K. (2010). Dziad wędrowny w kulturze ludowej Słowian. Przeł. H. Karpińska. Warszawa: Oficyna Naukowa.

Mokrzan, M. (2011). Pożytek z perswazji. Retoryka Społeczności wiejskiej. Łódzkie Studia Etnograficzne, 50, 131-153.

Morris-Reich, A. (2016). Race and Photography. Racial Photography as Scientific Evidence, 1876-1980. Chicago: University of Chicago Press.

Nola, A.M. di (2006). Tryumf śmierci. Antropologia żałoby. Przeł. J. Kornecka, M. Olszańska, R. Sosnowski, M. Surma-Gawłowska, M. Woźniak. Kraków: Universitas.

Nowicki, W. (2015). Odbicie. Wołowiec: Czarne.

Okely, J. (2012). Anthropological Practice. Fieldwork and the Ethnographic Method. London New York: Berg.

Parezo, N.J., Fowler, D.D. (2007). Anthropology Goes to the Fair. The 1904 Louisiana Purchase Exposition. Lincoln: University of Nebraska Press.

Perzanowski, A. (2009). Odmieńcy. Antropologiczne studium dewiacji. Warszawa: Instytut Etnologii i Antropologii Kulturowej Uniwersytetu Warszawskiego, Wydawnictwo DiG.

Pessel, W.K. (2010). Antropologia nieczystości. Studia z kultury sanitarnej Warszawy. Warszawa: Wydawnictwo Trio.

Pink, S. (2009). Doing Sensory Ethnography. London: SAGE.

Pink, S. (2010a). The Future of Sensory Anthropology/The Anthropology of the Senses. Social Anthropology, 3 (18), 331-333.

Pink, S. (2010b). Response to David Howes. Social Anthropology, 3 (18), 336-338.

Pinney, C. (2011). Photography and Anthropology. London: Reaction Books.

Pratt, M.L. (2011). Imperialne spojrzenie. Pisarstwo podróżnicze a transkulturacja. Przeł. E.E. Nowakowska. Kraków: Wydawnictwo Uniwersytetu Jagiellońskiego.

Puchta, W. (2016). Powszechna wystawa Krajowa we Lwowie w 1894 roku. Wrocław: Chronicon.

Qureshi, S. (2011). Peoples on Parade. Exhibitions, Empire, and Anthropology in Nineteeth-Century Britain. Chicago - London: University of Chicago Press.

Rabinow, P. (2010). Refleksje na temat badań terenowych w Maroku. Przeł. K.J. Dudek, S. Sikora. Kęty: Wydawnictwo Marek Derewiecki.

Raybeck, D. (1996). Mad Dogs, Englishmen, and the Errant Anthropologist. Fieldwork in Malaysia. Prospect Heights: Waveland Press.

Rothfels, N. (2002). Savages and Beasts. The Birth of the Modern Zoo. Baltimore - London: The Johns Hopkins University Press.

Ruby, J. (ed.) (1982). A Crack in the Mirror. Reflexive Perspectives in Anthropology. Philadelphia: University of Pennsylvania Press.

Ryan, J.R. (1997). Picturing Empire. Photography and the Visualization of the British Empire. Chicago: University of Chicago Press.

Ryziński, R. (2017). Foucault w Warszawie. Warszawa: Wydawnictwo Dowody na Istnienie. 
Sanjek, R. (ed.) (1990). Fieldnotes. The Makings of Anthropology. Ithaca: Cornell University Press.

Scheper-Hughes, N., Lock, M. (1987). The Mindful Body. A Prolegomenon to Future Work. Medical Anthropology Quarterly, 1, 6-41.

Shaffir, W.B., Stebbins, R.A. (eds.) (1991). Experiencing Fieldwork. An Inside View of Qualitative Research. Newbury Park: SAGE Publications.

Silverman, S. (2007). Stany Zjednoczone. W: F. Barth, A. Gingrich, R. Parkin, S. Silverman, Antropologia. Jedna dyscyplina, cztery tradycje: brytyjska, niemiecka, francuska i amerykańska (s. 285-382). Przeł. J. Tegnerowicz. Kraków: Wydawnictwo Uniwersytetu Jagiellońskiego.

Stagl, J. (1995). A History of Curiosity. The Theory of Travel 1550-1800. London - New York: Routledge.

Stocking, G.W. Jr (1982). Race, Culture, and Evolution. Essays in the History of Anthropology. Chicago: University of Chicago Press.

Stocking, G.W. Jr (1987). Victorian Anthropology. New York: The Free Press.

Stocking, G.W. Jr (ed.) (1983). Observers Observed. Essays on Ethnographic Fieldwork. Madison: University of Wisconsin Press.

Stoczkowski, W. (2005). Ludzie, bogowie i przybysze z kosmosu. Przeł. R. Wiśniewski. Warszawa: Państwowy Instytut Wydawniczy.

Stoller, P. (1989). The Taste of Ethnographic Things. The Senses in Anthropology. Philadelphia: University of Pennsylvania Press.

Stoller, P. (1995). Embodying Colonial Memories. Spirit Possession, Power, and the Hauka in West Africa. New York: Routledge.

Strządała, A. (2010). Od Galtona do Watsona. Przemiany pojmowania eugeniki w XIX i XX wieku. Opole: Wydawnictwo Uniwersytetu Opolskiego.

Swoboda, T. (2010). Historie oka. Bataille, Leiris, Artaud, Blanchot. Gdańsk: słowo/obraz terytoria.

Szerszeń, T. (2015). Podróżnicy bez mapy i paszportu. Michel Leiris i „Documents". Gdańsk: słowo/obraz terytoria.

Sztandara, M. (red.) (2012). Brud. Idee, dylematy, sprawy. Opole: Wydawnictwo Uniwersytetu Opolskiego.

Szyfer, A. (2006). Zapisane w pamięci. Z badań etnografa. Poznań: Wydawnictwo Poznańskiego Towarzystwa Przyjaciół Nauk.

Taussig, M. (1986). Shamanism, Colonialism, and the Wild Man. A Study in Terror and Healing. Chicago: University of Chicago Press.

Taussig, M. (1993). Mimesis and Alterity. A Particular History of the Senses. New York: Routledge.

Theweleit, K. (2009). Posłowie Klausa Theweleita. W: J. Littell, Suche i wilgotne. Krótka wyprawa na terytorium faszysty (s. 115-131). Przeł. M. Kamińska-Maurugeon. Kraków: Wydawnictwo Literackie.

Thomas, L.-V. (1991). Trup. Od biologii do antropologii. Przeł. K. Kocjan. Łódź: Wydawnictwo Łódzkie.

Todorov, T. (1996). Podbój Ameryki. Problem Innego. Przeł. J. Wojcieszak. Warszawa: Fundacja Aletheia.

Tokarska-Bakir, J. (1995). Dalsze losy syna marnotrawnego. Projekt etnografii nieprzeźroczystej. Konteksty, 1 (228), 13-22.

Tokarska-Bakir, J. (2007). Energia odpadków. W: M. Douglas, Czystość i zmaza (s. 7-43). Przeł. M. Bochulc. Warszawa: Państwowy Instytut Wydawniczy. 
Trebunia-Staszel, S. (2017). Naród - Rasa - Kultura. Nazistowskie badania rasowe i etnograficzne na Podhalu. W: J. Jasionowska, K. Kaniowska (red.), Colloquia Anthropologica II (s. 53-91). Warszawa: Oficyna Naukowa.

Turkawski, M. (1880). Wystawa etnograficzna Pokucia w Kołomyi. Kraków: Drukarnia „Czasu”. Turner, A. (2000). Embodied Ethnography. Doing culture. Social Anthropology, 8 (1), 51-60. Turner, V., Bruner, E. (red.) (2011). Antropologia doświadczenia. Przeł. E. Klekot, A. Szurek. Kraków: Wydowanictwo Uniwersytetu Jagiellońskiego.

Vigarello, G. (1996). Czystość i brud. Higiena ciała od średniowiecza do XX wieku. Przeł. B. Szwarcman-Czarnota. Warszawa: Wydawnictwo W.A.B.

Vigarello, G. (2011). Historia zdrowia i choroby. Praktyki sanitarne od średniowiecza do wspótczesności. Przeł. M. Szymańska. Warszawa: Fundacja Aletheia.

Vovelle, M. (2004). Śmierć w cywilizacji Zachodu. Od roku 1300 po wspótczesność. Przeł. T. Swoboda, M. Ochab, M. Sawiczewska-Lorkowska, D. Senczyszyn. Gdańsk: słowo/obraz terytoria.

Watson, C.W. (ed.) (1999). Being There. Fieldwork in Anthropology. London - Sterling: Pluto Press.

Werner, F. (2014). Ciemna materia. Historia gówna. Przeł. E. Kalinowska. Wołowiec: Czarne. Westerman, F. (2015). El Negro i ja. Przeł. M. Woźniak-Diederen. Warszawa: Wydawnictwo Dowody na Istnienie.

Węglarz, S. (1994). Chłopi jako „obcy”. Prolegomena. W: W. Burszta, J. Damrosz (red.), Pożegnanie paradygmatu? Etnologia wobec wspótczesności (s. 78-101). Warszawa: Instytut Kultury.

Wieczorkiewicz, A. (2009). Monstruarium. Gdańsk: słowo/obraz terytoria.

Wieczorkiewicz, A. (2013). Czarna kobieta na biatym tle. Dyptyk biograficzny. Kraków: Universitas.

Wróblewski, F. (2015). Zastosowanie koncepcji „aparatu” i „funkcjonariusza” Viléma Flussera w analizie kwestionariuszy etnograficznych. Prace Etnograficzne, 4, 329-345.

Wróblewski, F. (2016). Kwestionariusze etnograficzne i prawo zadawania pytań. Etnografia. Praktyki, Teorie, Doświadczenia, 2, 149-176.

Wróblewski, F. (2018). Etnograf w terenie. Gest (w) fotografii. Kultura Współczesna, 1, 126-143.

Wyka, A. (1996). Badacz społeczny wobec doświadczenia. Warszawa: Wydawnictwo Instytutu Filozofii i Socjologii Polskiej Akademii Nauk.

Young, D.E., Goulet, J.-G. (eds.) (1994). Being Changed. The Anthropology of Extraordinary Experience. Peterborough - Orchard Park: Broadview Press.

Zawistowicz-Adamska, K. (1948). Społeczność wiejska. Doświadczenia i rozważania z badań terenowych w Zaborowie. Łódź: Polski Instytut Służby Społecznej.

Żerkowski, M. (2015). Pożegnanie z terenem. Esej antropologiczny. Etnografia. Praktyki, Teorie, Doświadczenia, 1, 156-173.

II. Archiwalia

Archiwum Nauki PAN i PAU w Krakowie

K III-91/154.a Anna Kunachowicz, Wielce Szanowni i Drodzy Państwo, incipit: „Chciałam podziękować serdecznie”, list z dnia 8.06.1974, ss. 4, teczka „Korespondencja. Anna Kunachowicz”, spuścizna Mieczysława Gładysza.

K III-91/154.b Anna Kunachowicz, Wielce Szanowni i Drodzy Państwo, incipit: „Tak bardzo bym chciała”, list bez daty, ss. 3, teczka „Korespondencja. Anna Kunachowicz”, spuścizna Mieczysława Gładysza. 
Archiwum PAN w Warszawie Oddział w Poznaniu

P.III-23/132 Filmy $i$ zdjęcia etnograficzne wykonane przez Bożenę Stelmachowską. Powiat kartuski lit. A-M, teczka, spuścizna Bożeny Stelmachowskiej.

P.III-23/177 Filmy i zdjęcia fotograficzne amatorskie, turystyczne, artystyczne, kolekcyjne 1935-1956, teczka, spuścizna Bożeny Stelmachowskiej.

Ośrodek Dokumentacji i Informacji Etnograficznej PTL w Łodzi

AKL Anna Kowalska-Lewicka, Dziennik Badań. Obidowa pow. Nowy Targ. Luty 1953, maszynopis, ss. 19 (sygnatura własna).

EK Ewa Kamińska, Pamiętnik. Obidowa pow. Nowy Targ. Luty 1953, maszynopis, ss. 22 (sygnatura własna).

\section{Rozmówcy}

2010/008/B ～wywiad kwestionariuszowy, 28.06.2010, kobieta, lat 58.

2011/011/A $\quad$ wywiad kwestionariuszowy, 16.06.2011, kobieta, lat 87.

2011/011/C ～wywiad swobodny, 20.05.2015, kobieta, lat 91.

2011/024/A wywiad kwestionariuszowy, 17.12.2011, mężczyzna, lat 67.

2014/096/A wywiad swobodny, 22.01.2014, kobieta, lat 65.

2017/116/D ～wywiad swobodny, 12.06.2017, kobieta, lat 62.

\section{SUMMARY}

Dirt and disgust, or how to become an ethnographer. Part 1 . The filthiness of the Other

The article highlights the importance of hygiene and sensually experienced dirt during the ethnographic fieldwork to identify and shape the subjectivity of anthropologists. Dealing with impurities, the risk of pollution, disgust and aversion, sensing and bodily inconveniences, though anecdotal in the tales of fieldwork, seems to be one of the most important factors influencing the course of professional socialization within the framework of anthropological practice. This issue is presented in the context of anthropological theories that focus reflection on the body and the senses. In relation to them, the factors allowing to outline the historical, social and custom-related context concomitant the formation of the anthropological discourse and the hygiene regimes prevailing in the $19^{\text {th }}$ and $20^{\text {th }}$ centuries have also been indicated. Based on the empirical material, the author highlights the methods of conceptualizing the Other in the anthropological discourse. They are related to the category of dirt distinguished on the basis of the bourgeoisie and intelligence class distinction.

Keywords: dirt, senses, embodiment, distinction, aesthetics, judgement of taste, countryside, landscape, fieldwork 